American Journal of Law \& Medicine, 47 (2021): 264-290

(C) 2021 The Author(s). This is an Open Access article, distributed under the terms of the Creative Commons

Attribution licence (https://creativecommons.org/licenses/ by/4.0/), which permits unrestricted re-use, distribution, and reproduction in any medium, provided the original

\title{
Ruthless Utilitarianism? COVID-19 State Triage Protocols May Subject Patients to Racial Discrimination and Providers to Legal Liability
}

\author{
Miriam F. Weismann and Cheryl Holder ${ }^{\dagger}$
}

Key Words: coronavirus; discrimination; rationing; facially neutral standards; triage protocols; crisis standards of care

As the coronavirus pandemic intensified, many communities in the United States experienced shortages of ventilators, intensive care beds, and other medical supplies and treatments. Currently, there is no single national response to provide guidance on allocation of scarce health care resources. Accordingly, states have formulated various "triage protocols" to prioritize those who will receive care and those who may not have the same access to health care services when the population demand exceeds the supply. Triage protocols address general concepts of "fairness" under accepted medical ethics rules and the consensus is that limited medical resources "should be allocated to do the greatest good for the greatest number of people." $T$ The actual utility of this utilitarian ethics approach is questionable, however, leaving many questions about what is "fair" unanswered. Saving as many people as possible during a health care crisis is a laudable goal but not at the expense of ignoring patients's legal rights, which are not suspended during the crisis. This Article examines the triage protocols from six states to determine whose rights are being recognized and whose rights are being denied, answering the pivotal question: If there is potential for disparate impact of facially neutral state triage protocols against Black Americans and other ethnic groups, is this legally actionable discrimination? This may be a case of first impression for the courts to resolve.

\footnotetext{
${ }^{\dagger}$ Miriam F. Weismann, JD, LLM (taxation) is the Academic Director of the Healthcare MBA program at Florida International University. She is also a Professor of Business Law and Tax. Cheryl Holder, M.D., F.A.C.P., is the Interim Associate Dean of Diversity, Equity, Inclusivity, and Community Initiative, and Associate Professor, Wertheim College of Medicine, Florida International University, and is board certified in internal medicine. She has dedicated her medical career to serving underserved populations.

A special thanks to Dr. Stevie Martin, Cambridge University, and Dr. Harald Schmidt, University of Pennsylvania, for their participation in the research initiative that led to this paper and editorial assistance.

${ }^{1}$ Gina M. Piscitello et al., Variation in Ventilator Allocation Guidelines by US State During the Coronavirus Disease 2019 Pandemic: A Systematic Review, JAMA Network Open, June 19, 2020, at 2.
} 
"[B]lack Americans are 3.5 times more likely to die of COVID-19 than [W] hite Americans ... . Latinx people are almost twice as likely to die of the disease, compared with [W] hite people."

"Our civil rights laws protect the equal dignity of every human life from ruthless utilitarianism ... . HHS is committed to leaving no one behind during an emergency, and this guidance is designed to help health care providers meet that goal." - Roger Severino, Office of Civil Rights Director, U.S. Department of Health and Human Services. ${ }^{3}$

\section{INTRODUCTION}

As COVID-19, ${ }^{4}$ also referred to as coronavirus, intensified, many communities in the United States experienced shortages of ventilators and intensive care unit ("ICU") beds. ${ }^{5}$ The virus has placed unprecedented demand on the nation's health care systems. ${ }^{6}$ Conservative estimates ${ }^{7}$ show that the health needs created by COVID-19 far exceed the capacity of U.S. hospitals. ${ }^{8}$ Such demands have created the need to ration, or plan for rationing, medical equipment and interventions.

In response, some states have formulated various "triage protocols" to prioritize those who will receive care and those who may not have the same access to health care services when the population demand exceeds the supply. ${ }^{9}$ Triage protocols address general concepts of "fairness" under accepted medical ethics rules, and the consensus is

${ }^{2}$ Ana Sandoiu, Racial inequities in COVID-19-the impact on black communities, Med. News Today (June 5, 2020), https:/www.medicalnewstoday.com/articles/racial-inequalities-in-covid-19-the-impacton-black-communities [https://perma.cc/WHW2-JCNF] (citing Cary P. Gross et al., Racial and Ethnic Disparities in Population-Level Covid 19 Mortality, 35 J. Gen. Internal Med. 3097, 3097 (2020)).

${ }^{3}$ Press Release, U.S. Dep't. of Health \& Human Serv's, OCR Issues Bulletin on Civil Rights Laws and HIPAA Flexibilities That Apply During the COVID-19 Emergency (Mar. 28, 2020) https://www.hhs. gov/about/ news/2020/03/28/ocr-issues-bulletin-on-civil-rights-laws-and-hipaa-flexibilities-that-apply-during-the-covid19-emergency.html [https://perma.cc/7QX6-JLAS].

${ }^{4}$ COVID-19 is an acute respiratory disease that can be spread from person to person for which there is no known cure at the time of the submission of this article. See Things to Know about the COVID-19 Pandemic, CTR. FOR Disease CONTROL, https://www.cdc.gov/coronavirus/2019-ncov/your-health/need-to-know.html [https://perma.cc/QEM3-XAHU] (last updated Mar. 17, 2021).

${ }^{5}$ Fred Schulte et al., Millions of Older Americans Live in Counties with No ICU Beds as the Pandemic Intensifies, KAISER HeALth News (Mar. 20, 2020), https://khn.org/news/as-coronavirus-spreads-widelymillions-of-older-americans-live-in-counties-with-no-icu-beds/ [https://perma.cc/QV3H-W9TS] ("More than half the counties in America have no intensive care beds, posing a particular danger for more than 7 million people who are age 60 and up - older patients who face the highest risk of serious illness or death from the rapid spread of COVID-19...").

${ }^{6}$ See, U.S. Dep't of Health and Human Servs., Pandemic Influenza Plan: 2017 Update 27 (2017), https://www.cdc.gov/flu/pandemic-resources/pdf/pan-flu-report-2017v2.pdf [https://perma.cc/ 8DJL-LYVM].

${ }^{7}$ See Ezekiel Emanuel et al., Fair Allocation of Scarce Medical Resources in the Time of Covid-19, 382 N. ENG. J. MED. 2049, 2050 (2020) ("According to the American Hospital Association, there were 5198 community hospitals and 209 federal hospitals in the United States in 2018. In the community hospitals, there were 792,417 beds, with 3532 emergency departments and 96,500 ICU beds, of which 23,000 were neonatal and 5100 pediatric, leaving just under 68,400 ICU beds of all types for the adult population.").

${ }^{8}$ IMPERIAL COLL. COVID-19 RESPONSE TEAM, IMPACT OF NON-PHARMACEUTICAL INTERVENTIONS (NPIs) to Reduce COVID-19 Mortality and HealthCare Demand 7 (2020), https://www.imperial.ac.uk/ media/imperial-college/medicine/sph/ide/gida-fellowships/Imperial-College-COVID19-NPI-modelling-16-032020.pdf [https://perma.cc/T689-EHPK].

${ }^{9}$ See Emily C. Cleveland Manchanda et al., Crisis Standards of Care in the USA: A Systemic Review and Implications for Equity Amidst COVID-19, J. Racial \& EThnic Health Disparities (Aug. 13, 2020), https://doi.org/10.1007/s40615-020-00840-5 [https://perma.cc/KMW9-28MR]. 
that limited medical resources should be allocated to do the greatest good for the greatest number of people. ${ }^{10}$

This Article examines whether the triage protocols from six states, although facially race neutral, result in a discriminatory disparate impact based on race when applied. If so, this Article asks: Is this legally actionable discrimination? This Article concludes that the administration of the triage protocol guidelines does have the potential for disparate impact discrimination against Black Americans and other ethnic groups. Whether this form of disparate impact discrimination based on race is legally actionable may be a case of first impression in the courts.

\section{THE LEGAL REQUIREMENTS TO PROVIDE MEDICAL TREATMENT}

\section{A. EMTALA}

"Patient dumping" is the practice of refusing treatment due to a patient's lack of insurance or ability to pay. ${ }^{11}$ This practice started to proliferate in the early $1980 \mathrm{~s} .{ }^{12}$ Some hospital emergency departments and physicians refused to treat patients presenting for stabilization and emergency care. ${ }^{13}$ In many instances, patients received merely a perfunctory examination before being transferred in medically unstable conditions to safety net public hospitals. ${ }^{14}$ In response, Congress enacted the federal Emergency Medical Treatment and Active Labor Act ("EMTALA") 15 to eliminate patient dumping by providers refusing service based on the inability to pay. ${ }^{16}$ EMTALA imposes a legal duty on the hospital and its physicians to provide medical screening examinations, medical stabilization, ${ }^{17}$ and treatment of all individuals seeking emergency care, ${ }^{18}$ regardless of the individual's ability to pay. ${ }^{19}$ It does not matter, however, if the patient was denied EMTALA treatment for non-monetary reasons. The Supreme Court has held

\footnotetext{
${ }^{10}$ See generally John StUart Mill, Utilitarianism (7th ed. 1879).

${ }^{11}$ U.S. Comm'N on Civil Rights, Patient Dumping 1 (2014), http://www.eusccr.com/2014PAT DUMPOSD\%209282014-2.pdf [https://perma.cc/98FJ-RDDD].

${ }^{12}$ Id.

${ }^{13} I d$.

${ }^{14}$ See id. at 5-6.

${ }^{15}$ Emergency Medical Treatment and Labor Act, Pub. L. No. 99-272, 100 Stat. 82 (codified as amended at 42 U.S.C. $§ 1395 \mathrm{dd}$ (2012)) ("In the case of a hospital that has a hospital emergency department, if any individual... comes to the emergency department and a request is made ... for examination or treatment for a medical condition, the hospital must provide an appropriate medical screening examination within the capability of the hospital's emergency department, including ancillary services routinely available to the emergency department to determine if an emergency medical condition exists.").

${ }^{16}$ U.S. Comm'N ON Civil Rights, supra note 11 , at 5.

${ }^{17} 42$ U.S.C. $\S 1395 \mathrm{dd}(\mathrm{e})(3)(\mathrm{B})$ ("Stabilized" means that within reasonable medical certainty, "no material deterioration" should occur from or during the transfer).

${ }^{18} I d$. $§ 1395 \mathrm{dd}(\mathrm{e})(1)(\mathrm{A})$ ("The term 'emergency medical condition' means- a medical condition manifesting itself by acute symptoms of sufficient severity (including severe pain) such that the absence of immediate medical attention could reasonably be expected to result in - (i) placing the health of the individual (or, with respect to a pregnant woman, the health of the woman or her unborn child) in serious jeopardy, (ii) serious impairment to bodily functions, or (iii) serious dysfunction of any bodily organ or part; .....").

${ }^{19}$ Brenda Goodman \& Andy Miller, Lives lost amid ER violations, investigation finds, Ga. Health News (Nov. 29, 2018), https://www.georgiahealthnews.com/2018/11/investigation-finds-lives-lost-er-viola tions/ [https://perma.cc/3YRQ-S7BN ] (finding that 4,341 EMTALA violations occurred at 1,682 hospitals nationwide between 2008-18. EMTALA violations occurred more often at hospitals with fewer than 100 beds, with these hospitals accounting for 34 percent of violations); Laura L. Katz \& Marshall B. Paul, When $A$ Physician May Refuse to Treat a Patient, Physician News, https://physiciansnews.com/2002/02/14/when-aphysician-may-refuse-to-treat-a-patient/ [https://perma.cc/CT8G-FAXV].
} 
that no "improper motive," financial or otherwise, must be proved to find a provider has violated EMTALA. ${ }^{20}$

EMTALA applies to a medical condition like COVID-19 due to its "acute symptoms of sufficient severity (including severe pain) such that the absence of immediate medical attention could reasonably be expected to result in placing the health of the individual in serious jeopardy, cause serious impairment to bodily functions, or cause serious dysfunction of any bodily organ or part." ${ }^{21}$ The Centers for Medicare and Medicaid ("CMS") stated that hospitals and critical access hospitals ("CAHs") with emergency departments violate EMTALA if they "use signage that presents barriers to individuals, including those who are suspected of having COVID-19, from coming to the ED, or to otherwise refuse to provide an appropriate [medical screening examination] to anyone who has come to the ED for examination or treatment of a medical condition." 22 Thus, hospitals and CAHs rationing services may violate the legal obligation to screen and stabilize patients presenting to hospital emergency rooms for treatment. This is legally impermissible under EMTALA.

Moreover, it is not an excuse for providers to claim that a community has exhausted its supply of beds or ventilators. EMTALA compliance is mandated whenever a patient presents with an emergent condition that needs immediate stabilization. ${ }^{23}$

In situations where facilities may not have the necessary services or equipment, they should provide stabilizing interventions within their capability until the individual can be transferred. For example, in cases where the hospital does not have available ventilators, establishing an advanced airway and providing manual ventilation can assist in stabilizing the individual until an appropriate transfer can be arranged. ${ }^{24}$

There is nothing in the statute, regulations, or CMS guidelines that allows some patients to be denied treatment under triage protocols as an alternative to treatment. ${ }^{25}$

Patients do not have a direct right of action against physicians for failure to comply with EMTALA's requirements. ${ }^{26}$ Physicians may, however, still be subject to a patient tort claim for medical malpractice for failure to satisfy federal EMTALA

${ }^{20}$ Roberts v. Galen of Va., Inc., 525 U.S. 249, 250 (1999) (stating “" $[\mathrm{t}]$ he Court of Appeals held that in order to recover in a suit alleging a violation of $\$ 1395 \mathrm{dd}(\mathrm{b})$, a plaintiff must prove that the hospital acted with an improper motive in failing to stabilize her. Finding no support for such a requirement in the text of the statute, we reverse.").

${ }^{21} 42$ U.S.C. $§ 1395 \mathrm{dd}(\mathrm{e})(1)(A)$. EMTALA was enacted by Congress in 1986 as part of the Consolidated Omnibus Budget Reconciliation Act (COBRA) of 1985. Joseph Zibulewsky, The Emergency Medical Treatment and Active Labor Act (EMTALA): what it is and what it means for physicians, 14 BAYLOR U. MED. CTR Proc. 339, 339 (2001).

${ }^{22}$ Ctrs. For Medicare \& Medicaid Serv's, Frequently Asked Questions for Hospitals and Critical Access Hospitals Regarding EMTALA 1 (2020) (defining "emergency departments" as "EDs"), https://www.cms.gov/files/document/frequently-asked-questions-and-answers-emtala-part-ii.pdf [https://perma. $\mathrm{cc} / \mathrm{X} 7 \mathrm{NZ}-2 \mathrm{X} 94]$.

${ }^{23} I d$. at 4 .

24،"Under section 1135 of the Social Security Act, the Secretary of HHS may temporarily waive or modify certain Medicare, Medicaid, and Children's Health Insurance Program (CHIP) requirements to ensure that sufficient health care items and services are available to meet the needs of individuals enrolled in Social Security Act programs in the emergency area and time periods and that providers who provide such services in good faith can be reimbursed and exempted from sanctions (absent any determination of fraud or abuse)." CTRS. FOR MEDICARE \& Medicaid Servs., 1135 Waiver - At A Glance, https://www.cms.gov/Medicare/Provider-Enrollment-andCertification/SurveyCertEmergPrep/Downloads/1135-Waivers-At-A-Glance.pdf [https://perma.cc/5QH7-GTJA].

${ }^{25}$ See, e.g., 42 U.S.C. $§ 1395 \mathrm{dd}(\mathrm{e})(1)(\mathrm{A})$; CTRS. FOR Medicare \& MedicaId Servs., supra note 24.

${ }^{26}$ See B. Sony Bal, An Introduction to Medical Malpractice in the United States, 467 ClinICAL Orthopedics Related Res., 339, 340 (2009). 
requirements. ${ }^{27}$ There are still statutory consequences for physicians failing to comply, which include federal civil monetary penalties and, for repeated or flagrant violations, exclusion from the Medicare and Medicaid programs. ${ }^{28}$

\section{B. Physician Malpractice Liability}

While federal law does not provide a direct cause of action for malpractice against physicians for failure to treat, state law does. ${ }^{29}$ Under state law, physicians "have no duty to accept a patient, regardless of the severity of the illness." ${ }^{30}$ A physician's relationship with a patient is a voluntary, contracted one. ${ }^{31}$ Once a treatment relationship exists, however, the physician's legal duty requires the delivery of all necessary medical treatment to the patient unless the relationship is terminated by the patient or physician. ${ }^{32}$ The physician must provide the patient sufficient notice to enable the patient to seek alternative care. ${ }^{33}$ Medical malpractice is defined as "any act or omission by a physician during treatment of a patient that deviates from accepted norms of practice in the medical community and causes an injury to the patient." 34

To provide some relief from medical malpractice exposure during the COVID-19 crisis, Congress has proposed draft legislation called The Safe to Work $\mathrm{Act}^{35}$ to provide a "liability shield" protecting businesses and health care providers against workers, customers, and patients suing over COVID-related injuries. In summary, the proposed legislation would enact a five-year period of limited immunity for certain defendants in COVID-related personal injury and medical malpractice suits. ${ }^{36}$ These cases, normally filed in state civil courts, would fall under federal court jurisdiction with a one-year statute of limitations. ${ }^{37}$ Plaintiffs must also establish that a health care provider or business was grossly negligent or engaged in willful misconduct, and that it failed to make "reasonable efforts" to comply with applicable federal or state public health guidance. ${ }^{38}$ This standard means a claim of gross negligence could fail if a defendant "can establish it simply tried, but failed, to comply with coronavirus safety measures." 39

${ }^{27}$ Zibulewsky, supra note 21, at 341-42.

${ }^{28} 42$ U.S.C. $\$ 1395 \mathrm{dd}(\mathrm{d})(2)(\mathrm{A})$; see Coleman v. Deno, 01-1517 (La. 01/25/02) 813 So. 2d 303, 312 (for the proposition that the court upheld a malpractice claim against a physician for "patient dumping" and the improper transfer of a patient under EMTALA while hospitalized and under the physician's treatment).

${ }^{29}$ Bal, supra note 26.

${ }^{30} \mathrm{Id}$. at 342 ("A duty does not exist where no relationship is established between the doctor and patient.”).

${ }^{31}$ See Patient-Physician Relationships, Am. MED. Ass'N, https://www.ama-assn.org/delivering-care/ ethics/patient-physician-relationships [https://perma.cc/55C8-M7VA].

${ }^{32} \mathrm{Id}$.

${ }^{33}$ Valarie Blake, When Is a Physician-Patient Relationship Established?, 14 Am. Med. Ass'N J. ETHICs 403, 403 (May 2012).

${ }^{34} \mathrm{Bal}$, supra note 26 , at 340 .

${ }^{35}$ S. 4317, 116th Cong. (2020).

${ }^{36}$ Id. $\S 3(7)(\mathrm{A})$.

${ }^{37}$ Id. $\S 161$.

${ }^{38}$ Id. $\S \S 122,142$.

${ }^{39}$ S. 4317. Other salient features of the proposed legislation include: "The bill states that the liability shield is retroactive to Dec. 1 and will remain in effect until either Oct. 1, 2024, or the end of the national public health crisis as declared by the U.S. Department of Health and Human Services, whichever is later. If a coronavirus-related suit is filed in or removed to federal court, a plaintiff must provide an opinion from a medical expert essentially vouching for an injured party's claim. Plaintiffs are required to provide a list of the places they went and people they met in the 14-day period prior to experiencing symptoms, as well as any persons who visited their residence during that period. Overall awards can be reduced to account for payments made by so-called collateral sources such as insurance companies and government reimbursements. In cases where there are multiple defendants, defendants will only be responsible for a proportionate share of damages, and it will be 


\section{Treatment Waivers}

In March 2020, the U.S. Department of Health and Human Services ("HHS") and CMS issued official guidance on steps to relieve some of the mounting pressure on U.S. emergency departments. ${ }^{40}$ President Trump then issued an emergency declaration aimed at alleviating some of the EMTALA restrictions on facilities and providers, including a treatment waiver under section 1135 of the Social Security Act. ${ }^{41}$ Some authors have suggested that these section 1135 waivers provide broad protection to providers unable to deliver care in compliance with the EMTALA mandate. ${ }^{42}$ Yet, the breadth of the waiver is narrow in application, as indicated by the guidance's express language. First, the guidance provides in part:

EMTALA waivers can only impact transfers and (off-campus) alternative medical screening sites, which must be in compliance with the state's pandemic or emergency preparedness plan.

The waiver may obviate sanctions (citation and fines), but not necessarily an investigation.

The waiver may not necessarily limit [a provider's] civil or regulatory liability.

... .

... [H] ospitals must activate their own disaster plan. Hospitals should review their disaster plan to determine if it has any bearing on the waiver provisions and the state's pandemic or emergency preparedness plan. ${ }^{43}$

As this Article discusses in greater detail below, most hospitals do not have their own disaster preparedness plans, nor do many states have pandemic preparedness plans. ${ }^{44}$

Additionally, treatment waivers may not include a waiver of protection granted under federal civil rights laws. ${ }^{45}$ Hospitals that receive federal financial assistance remain obligated to comply with federal civil rights laws, including section 504 of the Rehabilitation Act, Title VI of the Civil Rights Act of 1964, section 1557 of the Patient Protection and Affordable Care Act ("ACA"), and the Hill-Burton Act. ${ }^{46}$

These legal duties to treat patients until stabilized and provide all necessary treatment that does not deviate from accepted norms of practice create a legal quandary for hospitals and physicians when demand for health care treatment exceeds the supply. Currently, the United States has no national criteria for allocating ICU beds, ventilators,

up to juries to determine the percentage of fault for each defendant. The bill includes a "loser pays" provision that allows prevailing defendants to seek compensatory and punitive damages if a claim outlined in a demand letter turns out to be meritless." Y. Peter Yang, GOP Sets Sights on COVID-19 Biz Immunity in Relief Bill, LAw360 (July 27, 2020, 9:57 PM), https://www.law360.com/articles/1295675/gop-sets-sights-on-covid-19-biz-immunityin-relief-bill [https://perma.cc/Z9B3-BUZH].

${ }^{40}$ Am. Coll. of Emergency Physicians, EMTALA, in ACEP COVID-19 Field Guide https:// www.acep.org/corona/covid-19-field-guide/regulations-and-liability/emtala/ [https://perma.cc/N2SC-49BT].

${ }^{41}$ Nisarg A. Patel, Joseph K. Yun \& Salim Afshar, Relieving Emergency Department Burden During COVID-19: Section 1135 Waivers for Dental Case Diversion, 78 J. Oral \& Maxillofacial Surgeons 2110, 2110-11 (2020).

${ }^{42}$ Heather L. Brown, Emergency Care EMTALA Alterations During the COVID-19 Pandemic in the United States, 47 J. Emergency Nursing 321, 323 (2021).

\footnotetext{
${ }^{43}$ Am. Coll. of Emergency Physicians, supra note 40, at 1.

${ }^{44}$ See discussion infra Section IV.

${ }^{45}$ Ctrs. For Medicare \& Medicaid Servs., supra note 22, at 4.

${ }^{46} I d$. at 11 .
} 
and other necessary medical treatment during an emergency like a pandemic. ${ }^{47}$ Accordingly, several states have formulated and adopted various countermeasures to address the COVID-19 crisis, called "triage protocols," to prioritize patients who will receive care and those who may not have the same access to health care services when the population demand exceeds the supply. ${ }^{48}$ The state triage protocol system, endorsed by HHS, is also designed in part to provide some legal relief to hospitals and physicians, although the extent of that protection is not clear given EMTALA's legislative mandate. ${ }^{49}$ Likewise, state triage protocols cannot waive the protections of federal civil rights laws. ${ }^{50}$

\section{THE LEGAL AUTHORITY TO ALLOCATE SCARCE HEALTH CARE RESOURCES DURING COVID-19}

\section{A. The Declaration of Immunity}

On March 17, 2020, HHS declared COVID-19 a public health emergency ${ }^{51}$ under the Public Readiness and Emergency Preparedness ("PREP") Act. ${ }^{52}$ The declaration provides liability immunity for activities related to medical countermeasures ${ }^{53}$ against COVID-19. ${ }^{54}$ The declaration provides some immunity from liability to certain entities responding to the COVID-19 pandemic. ${ }^{55}$ These immunity provisions may provide significant protection to manufacturers, distributors, and others including hospitals, physicians, ${ }^{56}$ and other health care professionals engaged in COVID-19-related efforts. The PREP Act was intended to directly impact states, providing "a source of potential liability protection for governmental and private sector persons developing and administering approved countermeasures during a public health emergency." ${ }^{\circ 7}$

\footnotetext{
${ }^{47}$ Alice Park \& Jeffrey Kluger, The Coronavirus Pandemic Is Forcing U.S. Doctors to Ration Care for All Patient, Time, Apr. 22, 2020, https://time.com/5825145/coronavirus-rationing-health-care/.

${ }^{48}$ Ryan C. Maves et al., Triage of Scarce Critical Care Resources in COVID-19 An Implementation Guide for Regional Allocation, 158 CHEST J. 212, 220 (2020); Cleveland Manchanda et al., supra note 9, at 1.

${ }^{49}$ Interim Guidance on Critical Care Resources Allocation for Direct - Service IHS Hospitals, DEP'T Health \& Human SeRvs. (Jan. 6, 2021), https://www.hhs.gov/civil-rights/for-providers/civil-rights-covid19/ ihs-interim-guidance/index.html [https://perma.cc/L5LX-QQNH].

${ }^{50} I d$.

${ }^{51}$ Declaration Under the Public Readiness and Emergency Preparedness Act for Countermeasures Against COVID-19, 85 Fed Reg. 15,198 (March 17, 2020) [hereinafter Declaration].

${ }^{52}$ Public Readiness and Emergency Preparedness Act, Pub. L. No. 109-148, 119 Stat. 2818 (2005) (codified at 42 U.S.C. $\S \S 247 d-6 d, 247 d-6 e$, amending Public Health Service (PHS) Act, ch. 373, Pub. L. No. 78410 , ch. 373,58 Stat. 682 (adding $\$ 319 F-3$ (liability immunity) and $\S 319 \mathrm{~F}-4$ (compensation program))).

${ }^{53}$ Declaration, supra note 51, at 15,199. A covered countermeasure must be a "qualified pandemic or epidemic product"; a "security countermeasure"; a drug, biological product, or device authorized for emergency use in accordance with various sections of the Federal Food, Drug, and Cosmetic Act; or certain approved respiratory protective devices. Id. Qualified pandemic and epidemic products may also include products that limit the harm such a pandemic or epidemic might otherwise cause. Id.

${ }^{54} I$. at 15,198

${ }^{55} \mathrm{Id}$.

${ }^{56} I d$. at 15,199 . The Declaration defines "covered persons" for purposes of its immunity provisions to include "a qualified person" defined as "a licensed health professional or other individual authorized to prescribe, administer, or dispense Covered Countermeasures under the law of the state in which the Covered Countermeasure was prescribed, administered or dispensed." Id. The term "person" includes an individual, partnership, corporation, association, entity, or public or private corporation, including a federal, state, or local government agency or department. $I d$.

${ }^{57}$ Emergency Authority and Immunity Toolkit, Ass'N OF State \& Territorial Health OfFs., https://www.astho.org/Programs/Preparedness/Public-Health-Emergency-Law/Emergency-Authority-andImmunity-Toolkit/Public-Readiness-and-Emergency-Preparedness-Act-Fact-Sheet/ [https://perma.cc/Z8QVYSAK] (last updated May 2013).
} 
The declaration raised questions, however, regarding the scope and applicability of the immunity provisions. ${ }^{58}$ On April 14, 2020, HHS issued an Omnibus Advisory Opinion ("Advisory Opinion") 59 that provides additional non-binding guidance on these topics. ${ }^{60}$ The Advisory Opinion states that immunity will cover "claims for loss sounding in tort or contract, as well as claims for loss relating to compliance with local, state, or federal laws, regulations, or other legal requirements," if the claim meets all requirements of the PREP Act and the declaration. ${ }^{61}$

According to the Advisory Opinion, "immunity applies when a covered person engages in activities related to an agreement or arrangement with the federal government, or when a covered person acts according to an Authority Having Jurisdiction to respond to a declared emergency." ${ }^{2}$ The Advisory Opinion interprets these two conditions broadly to include: "(1) any arrangement with the federal government, or (2) any activity that is part of an authorized emergency response at the federal, regional, state, or local level. Such activities can be authorized through, among other things, guidance, requests for assistance, agreements, or other arrangements." 63

Notably, PREP immunity is not absolute. ${ }^{64}$ PREP immunity does not apply to federal enforcement actions - criminal, civil, or administrative - when initiated by the federal government. ${ }^{65}$ The immunity prevents neither lawsuits nor liability for federal claims seeking equitable relief. ${ }^{66}$ Additionally, a covered person is not immune from liability for willful misconduct that proximately causes death or serious injury. ${ }^{67}$

\section{B. The Preemption Exclusion}

PREP also includes a preemption exclusion. ${ }^{68}$ The exclusion provides that "no State or political subdivision of a State may establish, enforce, or continue in effect with respect to a covered countermeasure any provision of law or legal requirement that is different from, or is in conflict with, any requirement applicable under this section." ${ }^{\prime 69}$ The statutory preemption exclusion makes clear that patients's legal rights were not intended to be suspended or otherwise preempted by state or local laws in conflict with PREP during the crisis. ${ }^{70}$

Indeed, on March 28, 2020, the HHS Office for Civil Rights ("OCR") issued a bulletin to ensure that health care entities "keep in mind their obligations under laws and

\footnotetext{
${ }^{58}$ Dep't of Health \& Human Servs., Advisory Op. 21-01 on the Public Readiness and Emergency Preparedness Act Scope of Preemption Provision (Jan. 8, 2021).

${ }^{59}$ Dep't of Health \& Human Servs., Advisory Op. On the Public Readiness and Emergency Preparedness Act and the March 10, 2020 Declaration under the Act April 17, 2020, as Modified ON MAY 19, 2020 (2020) [hereinafter AdVISORY OP.].

${ }^{60} I d$. at 1 . "It is not a final agency action or a final order. Nor does it bind HHS or the federal courts. It does not have the force or effect of law." Id.

${ }^{61} \mathrm{Id}$.

${ }^{62} I d$.

${ }^{63} \mathrm{Id}$.

${ }^{64} I d$.

${ }^{65} \mathrm{Id}$.

${ }^{66} I d$.

${ }^{67}$ Suits alleging an exception to immunity for covered persons can only be brought before a threejudge court in the United States District Court for the District of Columbia. 42 U.S.C. § 247d-6d(e)(1), (5) (2013). To prevail, a plaintiff must establish, by clear and convincing evidence, that the willful misconduct proximately caused death or serious injury. Id. $\S 247 \mathrm{~d}-6 \mathrm{~d}(\mathrm{c})(3)$.

${ }^{68} I d . \S 247 \mathrm{~d}-6 \mathrm{~d}(\mathrm{~b})(8)(\mathrm{A})$.

${ }^{69} \mathrm{Id}$.

${ }^{70} \mathrm{Cf}$. Kathleen Liddell et al., Who Gets the Ventilator? Important Legal Rights a Pandemic, $46 \mathrm{~J}$. Med. Ethics 421, 422 (2020) (arguing that "patients' legal rights are not suspended merely because a crisis has occurred.").
} 
regulations that prohibit discrimination on the basis of race, color, national origin, disability, age, sex, and exercise of conscience and religion in HHS-funded programs." ${ }^{71}$ The bulletin cautioned that the "laudable goal" of "providing care quickly and efficiently must be guided by the fundamental principles of fairness, equality, and compassion that animate our civil rights laws." 72 Likewise, the OCR Director emphasized that "HHS is committed to leaving no one behind during an emergency, and this guidance is designed to help health care providers meet that goal ... . Our civil rights laws protect the equal dignity of every human life from ruthless utilitarianism." 73

While PREP provides some immunity to hospitals and physicians, this immunity remains subject to the requirements of civil rights laws which are not suspended during a pandemic. While some states include a grant of immunity from litigation to protect providers implementing approved triage protocol designs, these protocols do not trump the protections afforded to claimants under the Constitution and federal civil rights laws. ${ }^{74}$

\section{The Interplay with Civil Rights Legislation}

The $\mathrm{ACA}^{75}$ includes section 1557, a nondiscrimination provision. ${ }^{76}$ Section 1557(a) "builds on a landscape of existing civil rights laws" 77 by incorporating four longstanding federal civil rights laws ${ }^{78}$ : 1) Title VI of the Civil Rights Act of 1964 (prohibiting "discrimination based on race, color, national origin, sex, age, or disability in certain health programs or activities"); ${ }^{79}$ 2) Title IX of the Education Amendments of 1972 (prohibiting discrimination on the basis of sex); ${ }^{80} 3$ ) section 504 of the Rehabilitation Act of 1973 (prohibiting discrimination on the basis of disability); ${ }^{81}$ and 4) Age Discrimination Act of 1975 (prohibiting discrimination on the basis of age). ${ }^{82}$

\footnotetext{
${ }^{71}$ HHS Office for Civil Rights in Action, BUlletin: Civil Rights, HiPAA, ANd the CORONAVIRUS DisEaSe 2019 (COVID-19) (2020), https://www.hhs.gov/sites/default/files/ocr-bulletin-3-28-20.pdf [https://perma.cc/Y3U5-NFRP].

${ }^{72} \mathrm{Id}$. at 1 .

${ }^{73} I d$.

${ }^{74} \mathrm{Cf}$. Ass'N OF State \& Territorial Health OfFs., supra note 57 (finding that the PREP Act does not people involved in willful misconduct or people who violate civil rights or the Americans with Disabilities Act, among other laws).

${ }^{75}$ Patient Protection and Affordable Care Act, Pub. L. No. 111-148, 124 Stat. 119 (2010) (codified as amended at 42 U.S.C. $§ 18001)$.

${ }^{76} I d$. $\$ 1557$ (codified as amended at 42 U.S.C. $\$ 18116$ ).

${ }^{77}$ Request for Information Regarding Nondiscrimination in Certain Health Programs or Activities, 78 Fed. Reg. 46558, 46559 (Aug. 1, 2013) (to be codified at 45 C.F.R. Subtitle A).

${ }^{78}$ The statute provides in pertinent part: "(a) In general. Except as otherwise provided for in this title (or an amendment made by this title), an individual shall not, on the ground prohibited under title VI of the Civil Rights Act of 1964, title IX of the Education Amendments of 1972, the Age Discrimination Act of 1975, or section 794 of title 29 , be excluded from participation in, be denied the benefits of, or be subjected to discrimination under, any health program or activity, any part of which is receiving Federal financial assistance, including credits, subsidies, or contracts of insurance, or under any program or activity that is administered by an Executive Agency or any entity established under this title (or amendments). The enforcement mechanisms provided for and available under such title VI, title IX, section 794, or such Age Discrimination Act shall apply for purposes of violations of this subsection.” 42 U.S.C. $\$ 18116$ (internal citations omitted).

$\S 2000 d)$.

${ }^{79}$ Civil Rights Act of 1964, Pub. L. No. 88-352, 78 Stat. 241 (codified as amended at 42 U.S.C.

${ }^{80}$ Education Amendments of 1972, Pub. L. No. 92-318, 86 Stat. 373 (codified as amended at 20 U.S.C. $\left.\S_{81} 1681\right)$.

${ }^{81}$ Rehabilitation Act of 1973, Pub. L. 93-112, title V, § 504, 87 Stat. 394 (codified as amended at 29 U.S.C. $\$ 794)$. $\S 6101)$
} 
Specifically, Title VI "protects persons from unlawful discrimination based on race, color, [or] national origin in programs and activities that receive federal financial assistance." ${ }^{83}$ Section 1557 of the ACA also "prohibits discrimination on the basis of race, color, [or] national origin ... in health programs or activities that receive Federal financial assistance or are administered by an Executive agency or any entity established under Title I of the ACA." 84

Significantly, HHS has clarified this ACA provision and declared that a providerrecipient of federal financial assistance may not provide a different service or other benefits as a part of a health or human service program based on race, color, or national origin. ${ }^{85}$ The same provision prohibits:

deny[ing] services or other benefits provided as a part of health or human service programs; ... segregat[ing] or separately treat[ing] individuals in any matter related to the receipt of any service or other benefit; utiliz[ing] criteria or methods of administration which subject individuals to discrimination; select[ing] a facility's site or location that excludes individuals or denies them benefits; [and] deny[ing] an individual an opportunity to participate on a planning or advisory board. ${ }^{86}$

The ACA and HHS provisions are targeted to prevent unequal medical treatment and unequal access to medical care based on race. Or, to put it another way, the rules prohibit disparate medical treatment based on race. The language of these rules goes further, prohibiting "utilization of criteria or methods of administration that have the effect of subject[ing] individuals to discrimination." ${ }^{87}$ HHS's position reflects a departure from prohibiting only intentional discrimination and expands protection to those subjected to criteria or methods of administration that have the impact of discrimination, even where no discrimination may have been intended in the first instance. ${ }^{88}$ State triage protocols employ certain metrics, known as Sequential Organ Failure Assessment ("SOFA") scoring, to prioritize patients who receive treatment and medical resource rationing and also to provide criteria that may subject Black Americans and other ethnic minorities to discrimination in their administration, as explained in the next Section. ${ }^{89}$ The language of the HHS rule is consistent with the OCR bulletin, noted above, which reminds providers that their respective obligations under the civil rights laws are in no way diminished

\footnotetext{
${ }^{83}$ Civil Rights FAQs, HHS.Gov, https://www.hhs.gov/civil-rights/for-individuals/faqs/index.html [https://perma.cc/Z7C8-MF56].

${ }^{84}$ Section 1557: Frequently Asked Questions, HHS.Gov, https://www.hhs.gov/civil-rights/forindividuals/section-1557/1557faqs/index.html [https://perma.cc/Y3SX-X5JJ].

${ }^{85}$ Nondiscrimination in Health Programs and Activities, 81 Fed. Reg. 31376, 31384 (May 18, 2016) (to be codified at 45 C.F.R. 92).

${ }^{86}$ Discrimination on the Basis of Race, Color, or National Origin, HHS.Gov, https://www.hhs.gov/ civil-rights/for-individuals/race/index.html [https://perma.cc/5U2P-PB76].

${ }^{87}$ Nondiscrimination in Health and Health Education Programs or Activities, 84 Fed. Reg. 27846, 27851 (June 14, 2019) (to be codified at 45 C.F.R. 92).

${ }^{88}$ Civil Rights Requirements- A. Title VI of the Civil Rights Act of 1964, 42 U.S.C. 2000d et seq. ("Title $\left.V I^{\prime \prime}\right)$, HHS.Gov, https://www.hhs.gov/civil-rights/for-individuals/special-topics/needy-families/civil-rightsrequirements/index.html [https://perma.cc/F3GS-FYQ8] ("This prohibition applies to intentional discrimination as well as to procedures, criteria or methods of administration that appear neutral but have a discriminatory effect on individuals because of their race, color, or national origin. Policies and practices that have such an effect must be eliminated unless a recipient can show that they were necessary to achieve a legitimate nondiscriminatory objective.").

${ }^{89}$ COVID-19 Resolutions, N.Y. STATE BAR Ass'N (Nov. 7, 2020) at 14. https://nysba.org/app/up loads/2021/01/health-Law-Resolutions-and-report-with-cover-approved-November-2020.pdf [https://perma. cc/HY3Q-ZXTE]. See generally David R. Williams \& Toni D. Rucker, Understanding and Addressing Racial Disparities in Health Care, 21 Health Care Fin. Rev. 75 (2000).
} 
during a pandemic..$^{90}$ In short, PREP immunity is not absolute and does not provide immunity for either intentional or disparate impact discrimination under section 1557.

\section{Understanding the Pattern of Disparate Impact: SOFA Scoring}

While it is unlikely that rationing medical treatment using an approved state triage protocol would be described as intentional discrimination under Title VI, even if it results in disparate treatment, the law recognizes a second form of discrimination known as disparate impact claims. ${ }^{91}$ Disparate treatment and disparate impact are two separate theories of discrimination. ${ }^{92}$ Disparate treatment is generally described as an intentional act to deny treatment based on race or other prohibited classification. ${ }^{93}$ Under disparate impact, a facially neutral policy or action is not intentionally discriminatory and a court can still find it in violation of the law if it has an especially adverse effect or disproportionate impact on a disability, sex, age, race or ethnic group. ${ }^{94}$ This Article focuses on the second theory.

The decision not to provide equal access to care can seemingly be framed as having an adverse disparate impact on a protected group. ${ }^{95}$ Indeed, the courts have held that systematic exclusion based on race, combined with continued unresponsiveness of elected officials to meet the needs of the Black community, establishes "racially invidious motivation." 96 Several researchers have observed that the COVID-19 pandemic affects everyone, but not equally. ${ }^{97}$ "The same patterns of power, privilege, and inequality that run throughout American life are recapitulated in this health crisis." 98 Whether intentional or not, the pale of discriminatory motivation may be envisioned in the implementation of state

${ }^{90}$ HHS OfFICE FOR Civil Rights IN ACTION, supra note 71, at 1 ("The Office for Civil Rights enforces Section 1557 of the Affordable Care Act and Section 504 of the Rehabilitation Act which prohibit discrimination on the basis of disability in HHS funded health programs or activities. These laws, like other civil rights statutes OCR enforces, remain in effect.").

${ }^{91}$ Williams \& Rucker, supra note 89, at 79 ("much discrimination today occurs through behaviors that the perpetrator does not subjectively experience as intentional. Much contemporary discriminatory behavior is unconscious, unthinking, and unintentional.”); accord Inst. of Med., Unequal Treatment: What Healthcare Providers Need to Know About Racial and Ethnic Disparities in Health-Care 4 (2002), https:// www.nap.edu/resource/10260/disparities_providers.pdf [https://perma.cc/96RR-9P8T]; Jennifer M. Orsi et al., Black-White Health Disparities in the United States and Chicago: A 15-Year Progress Analysis, 100 Am. J. PuB. Health 349, 349-56 (2010); Khiara Bridges, Implicit Bias and Racial Disparities in Health Care, 43 ABA Hum. Rights Mag. (2018).

${ }^{92}$ See sources cited supra note 91.

${ }^{93}$ Griggs v. Duke Power Co., 401 U.S. 424, 431 (1971) ("The [Civil Rights] Act proscribes not only overt discrimination but also practices that are fair in form, but discriminatory in operation.").

${ }^{94}$ The Supreme Court originated the theory of disparate-impact in the case Griggs v. Duke Power Co. Id. In Griggs, employees hired into service jobs by the power company had to have a high school diploma and satisfy a minimum IQ test score. Id. at 425-26. The plaintiffs argued that these two requirements disproportionately disqualified blacks in the application process and thus violated Title VII of the Civil Rights Act of 1964, which prohibits employment discrimination based on race, color, religion, sex, or national origin. Id. at 429 .

The Supreme Court agreed, ruling that "barriers that have operated in the past to favor an identifiable group of white employees over other employees ... [that are] neutral on their face, and even neutral in terms of intent" could violate the Title VII ban on race discrimination in hiring. Id. at 430. The Court further stipulated that employers have the burden of showing that their adverse selection practices had a "manifest relationship to the employment in question" or that they were justified by "business necessity." Id. at 431-32; Paul Ngobeni, Harms' Gauntlett Review - A Case of Judicial Chutzpah and Throwing Down the Gauntlet, Constitutional CrossROADS (Oct. 29, 2012), http://constitutionalcrossroads.blogspot.com/2012/10/ [https://perma.cc/RE6S-93G4].

${ }^{95}$ See Griggs, 401 U.S. at 431.

${ }^{96}$ Washington v. Davis, 426 U.S. 229, 243 (1976).

e76, e76 (2020).

${ }^{97}$ Seth A. Berkowitz et al., Covid-19 and Health Equity_Time to Think Big, 383 New Eng. J. Med. 
triage protocols that subject individuals to discrimination based on racial disparities in access to health care. Research shows that Black communities and ethnic minorities do not share in equal access to health care in the United States. ${ }^{99}$ Medical studies have concluded "that minorities are less likely than [White individuals] to receive needed services, including clinically necessary procedures." 100 As one consequence, Black individuals and ethnic minorities tend to develop a higher incidence of comorbidities ${ }^{101}$ than White individuals. ${ }^{102}$ Racism is significantly associated with poorer mental and physical health according to a meta-analysis of 293 studies. ${ }^{103}$

The higher incidence of comorbidities in minorities, already penalized by unequal health care access, has the actual effect of excluding Black individuals from medical treatment under the state triage protocols based on SOFA scores, which automatically penalize patients with higher comorbidities. ${ }^{104}$ For example, part of the SOFA metric relies on kidney function and the amount of creatinine present in the body. ${ }^{105}$ Creatinine is the waste from muscle breakdown passing through the kidneys. Studies have shown that Black individuals typically have higher creatinine levels. ${ }^{106}$ This observation gave rise to a faulty diagnosis that it was muscle mass and not kidney disease accounting for the higher levels of creatinine in Black individuals. ${ }^{107}$ The consequences were that Black individuals were not timely diagnosed and treatment was delivered only after the renal disease had become too severe. ${ }^{108}$ Black individuals are three times more likely than White individuals to have end stage kidney disease. ${ }^{109}$ Yet, Black individuals were not

${ }^{99}$ Williams \& Rucker, supra note 89 , at 75 (“'[B]lack persons continue to have higher rates of morbidity and mortality than white persons for most indicators of physical health. Hispanics and American Indians also have elevated disease and death rates for multiple conditions ... Compared with white persons, black persons and other minorities have lower levels of access to medical care in the United States due to their higher rates of unemployment and under-representation in good-paying jobs that include health insurance as part of the benefit package.”).

${ }^{100}$ InST. OF MED., supra note 91, at 2.

${ }^{101}$ Williams \& Rucker, supra note 89 , at 75.

${ }^{102} I d$.

${ }^{103}$ Leonard E. Egede \& Rebekah J. Walker, Structural Racism, Social Risk Factors, and Covid-19 A Dangerous Convergence for Black Americans, 383 New Eng. J. Med. e77(1), e77(1) (2020) (citing Yin Paradies et al., Racism as a Determinant of Health: A Systematic Review and Metal-Analysis, PLoS ONE, Sept. 23,2015 , at 1,24).

${ }^{104}$ SOFA is a mortality prediction score that predicts ICU mortality based on the extent of a person's organ function or rate of failure using six different scores, "one for each of the respiratory, cardiovascular, hepatic, coagulation, renal and neurological systems." Simon Lambden et al., The SOFA Score-Development, Utility and Challenges of Accurate Assessment in Clinical Trials, Critical CARE, Nov. 27, 2019, at 1, 2-3 (2019).

${ }^{105} \mathrm{Id}$. at 2, 5 ("The SOFA score is based on the clinical indices of creatinine or urine output, both of which will be affected by the presence of renal replacement therapy.").

${ }^{106}$ See Joy Hsu et al., Higher Serum Creatinine Concentrations in Black Patients with Chronic Kidney Disease: Beyond Nutritional Status and Body Composition, 3 Clinical J. Am. Soc'y Nephrology 992, 992, 995 (2008).

${ }^{107} I d$. at 992 ("Serum creatinine concentrations are significantly higher in black compared with nonblack hemodialysis patients; these differences are not readily explained by differences in nutritional status or body composition.").

${ }^{108}$ The SOFA kidney function measurement employs a formula that uses the amount of creatinine in the blood, with a correction for Blacks, still based on an assumption that all Blacks have more muscle mass, to determine the severity of kidney disease. Recent analysis shows that this correction probably underestimates the extent of Black kidney disease, resulting in late diagnosis and treatment. See Hsu et al., supra note 106, at 995 (noting that, although the prevalence of moderate chronic kidney disease is "roughly equivalent in black and white patients," end-stage renal disease is disproportionality greater in black patients).

${ }^{109}$ African Americans and Kidney Disease, NAT'L KidNEy Found., https://www.kidney.org/news/ newsroom/factsheets/African-Americans-and-CKD [https://perma.cc/F4GA-BAWR] (last updated Jan. 2016). 
receiving equal access to timely treatment. ${ }^{110}$ Significantly, this increase in the risk of renal failure in Black individuals adds points to the SOFA score and disadvantages Black individuals in the rationing process. ${ }^{111}$ This and other SOFA factors are referred to as exclusion criteria. ${ }^{12}$

SOFA scores are the metric most commonly adopted by states to justify rationing health care, ${ }^{113}$ as will be seen in the analysis of state triage protocols below. ${ }^{114}$ Studies have shown that the use of SOFA scoring as exclusion criteria has the potential to discriminate against certain populations including those in a lower socio-economic status who have higher comorbidities (due in part to limited health care access), the disabled, those with cognitive deficits, and children with certain medical abnormalities. ${ }^{115}$ Congresswoman Ayanna Pressley summarizes the point well:

Given ... the use of co-morbidities as a measure to determine which patients would receive critical care resources ... experts have voiced their concern about the devasting impact these protocols would have on communities of color .... . [B] arring proper action, COVID-19 would be a death sentence for Black and Latinx communities - not because communities of color are predisposed to the negative consequences of this disease, but because [of] ... [t]he legacy of structural racism and inequality [that] has resulted in unequal access to affordable health care, safe and stable housing, and quality schools and employment ... . Undoubtedly, this crisis will force our physicians and frontline healthcare workers ... to make difficult decisions ... [b]ut these decisions cannot be guided by a set of standards that devalues the lives of individuals with disabilities and people of color. ${ }^{116}$

\footnotetext{
${ }^{110}$ See Andy I. Choi et al., White/Black Racial Differences in Risk of End-Stage Renal Disease and Death, 122 Am. J. MeD. 672, 673, 676-77 (2009); Harald Schmidt, Opinion, The Way We Ration Ventilators Is Biased, N.Y. TImes (Apr. 15, 2020) https://www.nytimes.com/2020/04/15/opinion/covid-ventilator-rationingblacks.html (noting that, for historically disadvantaged groups, "[a]ccessing health care has been as challenging as accessing loans or healthy food").

${ }^{111}$ See Schmidt, supra note 110 ("For example, creatinine levels, which reflect kidney function, vary across income and racial groups. African-Americans, who have higher creatinine levels on average, would be assigned a higher risk.").

${ }^{112}$ See Dep't Critical Care Med., Univ. Pittsburgh, Allocation of Scarce Critical Care Resources During a Public Health Emergency: Executive Summary 2 (2020) ("There are compelling reasons to not use exclusion criteria. Categorically excluding patients will make many feel that their lives are 'not worth saving,' leading to justified perceptions of discrimination. Moreover, categorical exclusions are too rigid to be used in a dynamic crisis, when ventilator shortages will likely surge and decline episodically during the pandemic. In addition, such exclusions violate a fundamental principle of public health ethics: use the means that are least restrictive to individual liberty to accomplish the public health goal. Categorical exclusions are not necessary because less restrictive approaches are feasible, such as allowing all patients to be eligible and giving priority to those most likely to benefit.").

${ }^{113}$ For example, in a medical study conducted using 26 state guidelines used to determine ventilator rationing, 24 of the 26 states recommended objective scoring systems for the allocation of ventilators. SOFA scoring was recommended in 15 of the 26 state guidelines. Piscitello et al., supra note 1, at 1, 3 .

${ }^{114}$ Other models integrate SOFA scoring models to eliminate exclusion criteria that are not adjusted for the potential of discriminatory impact. However, even under the Pitt Model, higher SOFA scores may still result in lower priority for receiving care. See DeP'T Critical CARe Med., Univ. PitTsburgh, supra note 112 ("Categorical exclusions are not necessary because less restrictive approaches are feasible, such as ... giving priority to those most likely to benefit [from ventilators].").

${ }^{115}$ Piscitello et al., supra note 1 , at 7.

${ }^{116}$ Emily Cleveland Manchanda et al., Inequity in Crisis Standards of Care, 383 New ENG. J. MeD. E16(1), E16(1) (2020) (quoting Letter from Ayanna Pressley, U.S. Cong. Rep., to Charlie Baker, Gov. of the Commonw. of Mass. (Apr. 13, 2020), https://pressley.house.gov/sites/pressley.house.gov/files/Baker\%20Vacci nation\%20Equity\%20Letter.pdf [https://perma.cc/2TT6-MKPX]).
} 
SOFA scores prioritize patients with lower comorbidities to receive first access to limited medical resources before patients less likely to survive the virus due to poorer health and underlying medical conditions. ${ }^{117}$ This scoring metric idealizes the utilitarian philosophy that limited medical resources should be allocated "to do the greatest good for the greatest number of people." 118 The principle is claimed to be "fundamentally identityblind," and many states have endeavored to bar consideration of race and social factors to achieve a more equitable and fair outcome. ${ }^{119}$ Several researchers, however, conclude that "it will almost certainly ensure the opposite, with devastating effects on disadvantaged communities." 120

What makes this approach "ruthless utilitarianism" is that Black and ethnic minorities, who develop more serious comorbidities and who are unfairly excluded from equal access to health care in the first instance, are then punished a second time under the triage protocol designs - they are pushed to the back of the line to receive limited medical resources as a result of poorer health outcomes based on subjective judgments about the patient's ability to survive after treatment. ${ }^{121}$ Research concludes that:

Any degree of uncertainty a physician may have relative to the condition of a patient can contribute to disparities in treatment. Doctors must depend on inferences about severity based on what they can see about the illness and on what else they observe about the patient (e.g., race). The doctor can therefore be viewed as operating with prior beliefs about the likelihood of patients' conditions, "priors" that will be different according to age, gender, socioeconomic status, and race or ethnicity. When these priors are considered alongside information gathered in a clinical encounter, both influence medical decisions. ${ }^{122}$

An examination of state triage protocols below helps illustrate this point. ${ }^{123}$

Notably, before the enactment of section 1557 , no private cause of action was permitted for a disparate impact claim in health care based on race, color, national origin, or sex, despite medical proof of disparate impact. ${ }^{124}$ After its enactment, the OCR

${ }^{117}$ See K. Lee et al., Sequential Organ Failure Assessment Score and Comorbidity: Valuable Prognostic Indicators in Chronically Critically Ill Patients, 36 Anaesthesia \& InTEnsive Care 528, 533 (2008) (finding that SOFA is a predictor of survival in chronically critically ill patients); Lambden et al., supra note 104, at 2 .

${ }^{118}$ Julia Driver, The History of Utilitarianism, Stan. EnCyClopedia PhIL. (Sept. 22, 2014), https:// plato.stanford.edu/entries/utilitarianism-history [https://perma.cc/6RHP-SGGB] ("Jeremy Bentham and John Stuart Mill ... held that we ought to maximize the good, that is, bring about 'the greatest amount of good for the greatest number."); see also Schmidt, supra note 110 ("Many hospitals decide who gets [ventilators] by selecting patients most likely to benefit.").

${ }^{119}$ For example, Pennsylvania included an ethical consideration section in its interim CSC plan stating: "these standards will be applied equitably across populations in compliance with the Pennsylvania Human Relations Act (PHRA) and other state and federal anti-discrimination statutes and regulation which prohibit discrimination in regard to patient age, race, gender, creed, religion or exercise of conscience, color, sexual orientation, gender identity or expression, disability, ethnicity, national origin (including limited English proficiency), or socioeconomic status." Pa. Dep't of Pub. Health, Interim Pennsylvania Crisis StanDards of CARE For Pandemic Guidelines 12-13 (Version 2 2020), https://www.media.pa.gov/Pages/HealthDetails.aspx?newsid=771 [https://perma.cc/TR3N-AVDM].

${ }^{120}$ Cleveland Manchanda et al., supra note 116, at e16(2); accord Schmidt, supra note 110.

${ }^{121}$ See Cleveland Manchanda et al., supra note 116, at e16(2) (“'S] tructural inequities shorten black life expectancy and overemphasizing life-years [in crisis standards of care] will exacerbate the problem.").

${ }^{122}$ INST. OF MED., supra note 91, at 3.

${ }^{123}$ See discussion infra Section IV.C.

${ }^{124}$ See, e.g., Alexander v. Sandoval, 532 U.S. 275, 284, 293 (2001) (denying a private cause of action for a disparate impact claim of discrimination under Title VI of the Civil Rights Act). 
interpreted section 1557 to allow such a claim in its May 2016 regulation. ${ }^{125}$ This regulatory interpretation by HHS greatly expanded the reach of unintentional discrimination claims in health care. Several courts have since agreed that section 1557 creates a private right of action and a private remedy to litigants, ${ }^{126}$ however, the few cases decided under section 1557 since its inception have narrowed its application.

\section{E. Is a Claim Based on the Disparate Impact of Facially Neutral State Triage Protocols Actionable?}

A handful of state and federal courts have decided cases alleging section 1557 violations. Most of these cases are not based on race as the prohibited classification. The cases typically arise in the context of discrimination against the disabled, another protected class. ${ }^{127}$ Additionally, courts have grappled with how to assess section 1557 claims given the incorporation of different anti-discrimination statutes into section 1557 that require varying standards of proof. ${ }^{128}$ The issue of whether a disparate impact claim is actionable based on race under section 1557 is less clear and remains a matter of first impression. Only two courts so far have ruled directly on the disparate impact question —one is based on sexual discrimination and the other is based on race. ${ }^{129}$ The two courts are split. One court holds that plaintiffs have a private right of action for disparate impact discrimination under section 1557, while the other court held that only claims for intentional discrimination are actionable. ${ }^{130}$

In Rumble v. Fairview Health Services, a transgender man sued under section 1557, alleging that a hospital emergency department discriminated against him based on his gender identity. ${ }^{131}$ Plaintiff alleged that the treating physician was hostile and disparaging and asked inappropriate questions about plaintiff's sexual activity. ${ }^{132}$ The plaintiff

\footnotetext{
${ }^{125}$ Dep’t of Health \& Hum. Servs., Summary: Final Rule Implementing Section 1557 of The AfFordable Care ACt 2, https:/www.hhs.gov/sites/default/files/2016-06-07-section-1557-final-rulesummary-508.pdf [https://perma.cc/65UR-HTC7]. But see Bostock v. Clayton Cnty., 140 S.Ct. 1731, 1740 (2020) (alterations in original) (citing Watson v. Forth Worth Bank \& Trust, 487 U.S. 977, 986 (1988)) ("In socalled "disparate treatment" cases like today's, this Court has also held that the difference in treatment based on sex must be intentional).

${ }^{126}$ See Esparza v. Univ. Med. Ctr. Mgmt. Corp., No. 17-4803, 2017 U.S. Dist. LEXIS 142944, at *9 (E.D. La. Sept. 5, 2017); Callum v. CVS Health Corp., 137 F. Supp. 3d 817, 847-848 (D. S.C., 2015); Se. Pa. Transp. Auth. v. Gilead Scis., Inc., 102 F. Supp. 3d 688, 698 (E.D. Pa. 2015); Rumble v. Fairview Health Servs., No. 14-cv-2037, 2015 U.S. Dist. LEXIS 31591, at*18 (D. Minn. 2015).

${ }^{127}$ See, e.g., Schmitt v. Kaiser Found. Health Plan of Wash., 965 F.3d 945, 948 ( $9^{\text {th }}$ Cir. 2020); Doe v. BlueCross BlueShield of Tenn., Inc., 926 F.3d 235, 238 ( $6^{\text {th }}$ Cir. 2019); Bax v. Doctors Med. Ctr. Of Modesto, Inc., 393 F.Supp.3d 1000, 1004, 1009 (E.D. Cal. 2019).

${ }^{128}$ See, e.g., Rumble, 2015 U.S. Dist. LEXIS 31591, at *27 (holding “[c]ongress intended to create a new, health-specific, anti-discrimination cause of action that is subject to a singular standard, regardless of a plaintiff's protected class status"); see also Se. Pa. Transp. Auth., 102 F. Supp. 3d at 698-699 (“[C]ongress's express incorporation of the enforcement mechanisms from th[e] four federal civil rights statutes, as well as its decision to define the protected classes by reference thereto, manifest[ed] an intent to import the various different standards and burdens of proof into a Section 1557 claim, depending upon the protected class at issue"). In explaining its disagreement with the Rumble court, the Gilead court continued, "[w]e do not find that adopting an interpretation of the statute whereby standards and burdens change based on a plaintiff's protected class status to be "patently absurd."' $I d$. at 699 . Had Congress intended for a uniform standard, the court explained, it could have listed the protected classes without reference to the civil rights statutes, and it could have expressly provided for one enforcement mechanism. Id.

${ }^{129}$ See, e.g., Cruz v. Zucker, 116 F. Supp. 3d 334, 348 (S.D.N.Y. 2015) (finding no proof that policy had disparate-impact on transgender people); Rumble, 2015 U.S. Dist. LEXIS 31591, at *77 (finding physician conduct resulted in disparate- impact on transgender hospital patient).

${ }^{130}$ Se. Pa. Transp. Auth., 102 F. Supp. 3d at 698, 701; Rumble, 2015 U.S. Dist. LEXIS 31591, at*17, 77.

${ }^{131}$ Rumble, 2015 U.S. Dist. LEXIS 31591.

${ }^{132} I d$. at $* 9$.
} 
also alleged that the hospital staff did not attend to him with the same degree of urgency as they attended to other patients and thus denied him the same access to health care. ${ }^{133}$ The defendants moved to dismiss the section 1557 claim, arguing that different legal standards applied to the four different anti-discrimination statutes incorporated under section 1557, and that the plaintiff had failed to show "discriminatory intent" under Title IX, or that the physicians treated him differently because of his transgender status. ${ }^{134}$

The plaintiff claimed that a single uniform standard of proof should be applied to section 1557 claims, regardless of which anti-discrimination provision was being asserted. ${ }^{135}$ Finding this a case of first impression, the court denied the motion to dismiss and held that "Congress intended to create a new, health-specific, anti-discrimination cause of action that is subject to a singular standard, regardless of a plaintiff's protected class status." "136 The court noted that "even if the Title IX discriminatory intent standard applied, the plaintiff had met the standard by alleging that the doctor discriminated against him and denied him the benefits of medical care to which he was entitled."137

In contrast to Rumble, the court in Southeastern Pennsylvania Transportation Authority v. Gilead Sciences, Inc. held that the plaintiff failed to state a cause of action in its section 1557 disparate impact claim of discrimination against a pharmaceutical manufacturer. ${ }^{138}$ SEPTA, the Philadelphia regional transit authority and plaintiff in this case, maintained an employee health and welfare benefit plan that provided employees prescription drug coverage. ${ }^{139}$ The plaintiff alleged that Gilead Sciences engaged in a "price gouging scheme" for its hepatitis $\mathrm{C}$ drugs, invoking the incorporated anti-discrimination sections under section 1557, including section 504 of the Rehabilitation Act and Title VI of the Civil Rights Act. ${ }^{140}$ The plaintiff argued that Gilead's pricing resulted in a demonstrable disparate impact on those with disabilities and discriminated against racial minorities resulting from Gilead's deliberate indifference to the fact that "[h]epatitis $\mathrm{C}$ victims [are] disproportionately African Americans." 141

The Gilead court expressly rejected the holding in Rumble and found that "Congress's express incorporation of the enforcement mechanisms from th[e] four federal civil rights statutes, as well as its decision to define the protected classes by reference thereto, manifest[ed] an intent to import the various different standards and burdens of proof into a Section 1557 claim, depending upon the protected class at issue." ${ }^{142}$ In explaining its disagreement with Rumble, the Gilead court stated that "[w]e do not find that adopting an interpretation of the statute whereby standards and burdens change based on a plaintiff's protected class status to be "patently absurd." ${ }^{143}$ The court noted that had "Congress intended for a uniform standard, it could have listed the protected classes without reference to the civil rights statutes, and it could have expressly provided for

${ }^{133} \mathrm{Id}$. at $* 69$.

${ }^{134} I d$. at $* 27, * 38$.

${ }^{135} \mathrm{Id}$. at $* 27$.

${ }^{136} \mathrm{Id}$. at $* 29$.

${ }^{137}$ William Stoeri \& Jillian Kornblatt, Health Care Discrimination Litigation Gets a New Set of Teeth under the ACA: 2015 Litigation Review and Preview of 2016, DORSEY \& WhiTNEY LLP (Mar. 29, 2016), https:// www.dorsey.com/newsresources/publications/client-alerts/2016/03/health-care-discrimination-change-under-aca [https://perma.cc/2HY4-FS8D] (citing Rumble, 2015 U.S. Dist. LEXIS 31591, at *38).

${ }^{138} \mathrm{Se}$. Pa. Transp. Auth., 102 F. Supp. 3d at 688.

${ }^{139} \mathrm{Id}$. at 695 .

${ }^{140} \mathrm{Id}$. at 696 .

${ }^{141} \mathrm{Id}$.

${ }^{142} I d$. at $698-99$.

${ }^{143} \mathrm{Id}$. at 699 . 
one enforcement mechanism." 144 The court likewise concluded that a private right of action under Title VI itself is available only for allegations of intentional discrimination and not disparate impact, citing the pre-section 1557 Supreme Court decision in which the Court denied a private cause of action for a disparate impact claim of discrimination under Title VI of the Civil Rights Act (which prohibits discrimination on the basis of race, color, or national origin in federally-funded health care). ${ }^{145}$

Still, the question of whether section 1557 creates a private right of action for a disparate impact claim of discrimination under Title VI is of great consequence to health care providers, given the challenge of rationing care during a pandemic. ${ }^{146}$ The state triage protocol immunity and rationing provisions may provide a case of first impression if tested in the courts.

\section{THE CASE FOR DISPARATE IMPACT: FIVE STATE TRIAGE PROTOCOL MODELS}

\section{A. Crisis Standards of Care Guidelines}

Rationing medical resources has become a critical issue in several states as the number of patients contracting the coronavirus has increased. In March 2020, the governors of Arizona, ${ }^{147}$ Florida, ${ }^{148}$ California, ${ }^{149}$ Georgia, ${ }^{150}$ and New York ${ }^{151}$ declared a state of emergency based on the coronavirus. By March 17, 2020, forty-eight states had followed suit. ${ }^{152}$ Following the emergency declarations, states drafted new or prepared Crisis Standards of Care ("CSC") guidelines which provide in part for the method to ration health care services when patient demand exceeds medical services supply. ${ }^{153}$ The National Academies of Sciences, Engineering, and Medicine ("NASEM") issued general

${ }^{144}$ Stoeri \& Kornblatt, supra note 137 (citing Se. Pa. Transp. Auth., 102 F. Supp. 3d at 688).

${ }^{145}$ Andrew C. Stevens, In a Class Action, a Federal Court Rejects HHS OCR Interpretaion of ACA Section 1557 and Limits the Reach of Unintentional Discrimination Claims in Healthcare, ARNALL GoLDEN GREGORY LLP (Jan. 16, 2017), https://www.agg.com/news-insights/publications/in-a-class-action-a-federalcourt-rejects-hhs-ocr-interpretation-of-aca-section-1557-and-limits-the-reach-of-unintentional-discriminationclaims-in-healthcare-01-16-2018/ [https://perma.cc/7ZPY-H2D3] (citing Alexander v. Sandoval, 532 U.S. 275, 293 (2001)).

${ }^{146}$ Dayna Bowen Matthew, Structural Inequality: The Real COVID-19 Threat to America's Health and How Strengthening the Affordable Care Act Can Help, 108 Geo. L.J. 1679, 1710-16 (2020).

${ }^{147}$ Douglas A. Ducey, Governor of Ariz., Declaration of Emergency (Mar. 11, 2020), https:// azgovernor.gov/sites/default/files/eo_2020-07.pdf [https://perma.cc/ZJP5-TWZC].

${ }^{148}$ Ron Desantis, Governor of Fla., Executive Order Establishes COVID-19 Response Protocol and Directs Public Health Emergency, Exec. Order No. 20-51 (Mar 9, 2020), https://www.flgov.com/wp-content/ uploads/orders/2020/EO_20-51.pdf [https://perma.cc/ZGB3-J5XJ].

${ }^{149}$ Gavin Newsom, Governor of Cal., Proclamation of a State of Emergency (Mar. 4, 2020), https:// www.gov.ca.gov/wp-content/uploads/2020/03/3.4.20-Coronavirus-SOE-Proclamation.pdf [https://perma.cc/ KV28-X7WL].

${ }^{150}$ Brian P. Kemp, Governor of Ga., Declaration of Public Health State Emergency, Exec. Order No. 03.14.20.01 (Mar. 14, 2020), https://gov.georgia.gov/executive-action/executive-orders/2020-executive-or ders [https://perma.cc/RDR6-569X].

${ }^{151}$ Andrew M. Cuomo, Governor of N.Y., Executive Order Declaraing a Disaster Emergency in the State of New York, N.Y. Exec. Order No. 202 (Apr. 6, 2020), https://www.governor.ny.gov/news/no-202declaring-disaster-emergency-state-new-york [https://perma.cc/JA32-LWFJ].

${ }^{152}$ Rosie Pepper, Ellen Cranley \& Sarah Al-Arshani, Almost all US states have declared states of emergency to fight coronavirus - here's what it means for them, BUs. INSIDER (Mar. 17, 2020, 1:34AM) https://www.businessinsider.com/california-washington-state-of-emergency-coronavirus-what-it-means-2020-3 [https://perma.cc/L9F2-E7Z9].

${ }^{153}$ See Cleveland Manchanda et al., supra note 9. 
guidelines for state guidance in implementing CSC protocols. ${ }^{154}$ The protocols are formulated and issued by states in the form of triage protocols. ${ }^{155}$ Following the NASEM guidelines is voluntary. ${ }^{156}$

The NASEM guidelines provide that CSC are to be activated when a pervasive or catastrophic disaster make it "impossible" to meet usual health care standards recognizing that "while CSC strive to save the most lives possible, some individual patients will die, who would survive under usual care and implementation of CSC will require facilityspecific decisions regarding the allocation of limited resources, including how patients will be triaged to receive life-saving care." ${ }^{157}$ Notably, the guidelines do not define the term "impossible." 158

Recognizing that the decision to provide care to some and not to others raises the specter of legal liability, the NASEM guidelines state that "health care workers who must make difficult decisions implementing CSC must have adequate guidance and legal protections." 159 NASEM cautions that under disaster conditions, "adherence to core constitutional principles remains a constant, but other statutory or regulatory provisions can be altered as necessary in real time." 160

The law must inform CSC and create incentives for protecting the public's health and respecting individual rights. Extreme scarcity can necessitate difficult life-and-death decisions. Health care workers who will have to make them must have adequate guidance and legal protections. They must be able to follow the rule of law, even under disaster conditions. ${ }^{161}$

Almost immediately after issuing triage protocols under CSC, state disability activists questioned several states's protocols. ${ }^{162}$ As a result, the OCR Director declared that the CSC protocols adopted by Washington and Alabama discriminated against the disabled. ${ }^{163}$ He rejected any protocols that had the potential to place "[p]ersons with disabilities, with limited English skills and older persons ... at the end of the line for health care during emergencies," 164 noting that new investigations would be conducted to ensure compliance with civil right laws during the pandemic. The conclusion was not predicated on any finding of intentional discrimination but rather upon a determination that the guidelines subjected the disabled to unfair treatment in the administration of the state respective protocols. ${ }^{165}$

${ }^{154}$ Letter from Harvey V. Fineberg, M.D., Ph.D., Chair, Standing Committee on Emerging Infectious Diseases and $21^{\text {st }}$ Century Health Threats, to ADM Brett Giroir, M.D., Assistant Secretary for Health \& Robert Kadlec, M.D., Assistant Secretary for Preparedness and Response, U.S. Dep't of Health (Mar. 28, 2020), https:// assets.documentcloud.org/documents/6960735/Res.pdf [https://perma.cc/5MQC-FC4T].

${ }^{155} I d$.

${ }^{156} \mathrm{Id}$.

${ }^{157}$ Id. at 2.

${ }^{158} \mathrm{Id}$.

${ }^{159} I d$. at 3.

${ }^{160} \mathrm{Id}$.

${ }^{161}$ Id. at 5 .

${ }^{162}$ E.g., Crisis Standards of Care Must be Revised for At-Risk Populations during COVID-19 Crisis, Ariz. Center Disability L. (June 30, 2020), https:/www.azdisabilitylaw.org/crisis-standards-of-care-mustbe-revised-for-at-risk-populations-during-covid-19-crisis/ [https://perma.cc/B7E6-7YV8].

${ }^{163}$ Sheri Fink, U.S. Civil Rights Office Rejects Rationing Medical Care Based on Disability, Age N.Y. Times (Mar. 28, 2020), https://www.nytimes.com/2020/03/28/us/coronavirus-disabilities-rationingventilators-triage.html.

${ }^{164}$ HHS OfFice FOR Civil Rights in Action, supra note 71.

${ }^{165}$ Fink, supra note 163 , at 2. 
While OCR has made it clear that discrimination will not be tolerated based on age and disability specifically and race generally, it has yet to publicly investigate the potential of sending minorities to the end of the line for health care during COVID-19. As this Article illustrates, the same problem based on disability as a prohibited classification applies equally to metrics that have the effect of sending Black individuals and ethnic minorities to the end of the line based on a history of unequal access to health care.

\section{B. SOFA Triage Protocol Design: Facially Neutral Standards}

Most states use a priority point system formula in their existing triage protocols. ${ }^{166}$ The formula specifies the order in which a provider must ration a needed resource, like a ventilator, for patients. ${ }^{167}$ The priority order is determined by patient mortality risk. Using mortality risk, a patient's priority assignment is reevaluated every forty-eight hours to determine if there is any change in health status. ${ }^{168}$ Mortality risk is measured by the SOFA score. ${ }^{169}$ Simply, "each of six organ systems - lungs, liver, brain, kidneys, blood clots, and blood pressure - is independently assigned a score of 1 to $4 . "{ }^{170}$ The SOFA score "totals these six scores, with sicker patients generally being assigned higher scores." 171

In July 2020, a panel of experts from the American College of Chest Physicians ("CHEST") published principles of critical care triage to "direct limited resources toward patients most likely to benefit from them" during the COVID-19 crisis. ${ }^{172}$ These triage protocols are designed to be implemented when "surge capacity" 173 is exceeded and there is a need to allocate scarce medical resources. ${ }^{174}$ Many states have incorporated these guidelines which provide operational steps to implement a triage system within a state, county, or jurisdiction. ${ }^{175}$ CHEST recommends the use of "tertiary triage":

[T] ertiary triage takes place at an acute care hospital when deciding whether or not to admit for critical care services. In a broad sense, patients who present for tertiary triage are going to fit into one of three categories: (1) too well to benefit from critical care, (2) too sick to benefit from critical care because of severe underlying illness or a poor likelihood of surviving their hospitalization, or (3) sick enough to benefit from critical care. The goal is not to exclude categories of patients based on age or underlying co-morbidities and disease ... . Rather, the goal of a triage protocol is to maximize the use of critical care resources for patients in the third category. These categories apply

\footnotetext{
${ }^{166}$ Accord Parag A. Pathak et al., Leaving No Ethical Value Behind: Triage Protocol Design for Pandemic Rationing (Nat'l Bureau of Econ. Research, Working Paper No. 26951, Apr. 2020), https://www. nber.org/papers/w26951 [https://perma.cc/G59L-S67W]; see Piscitello et al., supra note 1.

${ }^{167}$ Pathak et al., supra note 166.

${ }^{168}$ N.Y. State Task Force on Life \& Law, Ventilator Allocation Guidelines 14 (2015), https://www.health.ny.gov/regulations/task_force/reports_publications/docs/ventilator_guidelines.pdf [https:// perma.cc/L6PE-7SMV].

${ }^{169}$ Pathak et al., supra note 166 , at 3.

${ }^{170}$ Id. at 3 n. 3 .

${ }^{171} \mathrm{Id}$.

${ }^{172}$ Maves, supra, note 48, at 215.

${ }^{173}$ Policy Statement by American College of Emergency Physicians, Health Care System Surge Capacity Recognition, Preparedness, and Response (Oct. 2017) https:/www.acep.org/patient-care/policystatements/health-care-system-surge-capacity-recognition-preparedness-and-response/ [https://perma.cc/GJ994EJW].

${ }^{174} I$. .

${ }^{175}$ Maves, supra, note 48 , at 213.
} 
to all patients presenting with critical illness under crisis standards of care, not just those infected with SARS-CoV-2. ${ }^{176}$

CHEST concludes that it is necessary to "recognize that patients less likely to benefit from critical care may not be provided those services and interventions under a triage system." 177

Referring to singular reliance on SOFA scores, CHEST expressly recognizes that "protocols that explicitly exclude patients based on a single criterion alone may run afoul of antidiscrimination laws in many jurisdictions." ${ }^{178}$ CHEST further recommends against the use of SOFA scoring because "a growing body of evidence suggests such scoring systems are unlikely to predict critical care outcomes with sufficient accuracy, in particular patients suffering from COVID-19, or be a useful basis for triage decisions based on the current protocol cut points." 179

Medical ethicists likewise contest the use of priority point systems like SOFA for ignoring ethical values. ${ }^{180}$ Many argue that at any patient priority level, there is a "potential that one priority group could completely exhaust the remaining available resources," leaving remaining patients without access. ${ }^{181}$ Still, Arizona, Florida, California, Georgia, and New York rely on SOFA scoring to ration health care. Arizona was the only state as of June 30, 2020 to initiate its triage protocol. ${ }^{182}$

\section{Disparate Impact Discrimination: Examples from State Triage PROTOCOLS}

On April 9, 2020, HHS published a state-by-state listing of CSC guidelines. ${ }^{183}$ HHS determined that seventeen states had not published guidelines as of that date: Alaska, Delaware, Georgia, Hawaii, Idaho, Indiana, Montana, New Hampshire, North Carolina, North Dakota, Rhode Island, South Carolina, South Dakota, Virginia, West Virginia, Wisconsin, and Wyoming. ${ }^{184}$

Only thirteen states had devised plans in 2020 in direct response to COVID-19: Alabama, California, Colorado, Florida, Kentucky, Maryland, Massachusetts, Minnesota, Nevada, Pennsylvania, Tennessee, Utah, and Washington. ${ }^{185}$ As discussed below, in several of these states, the government did not devise the CSC. ${ }^{186}$ In Florida, for example, a private organization stepped in to create a plan endorsed by the Florida Hospital Association when the state government failed to act. ${ }^{187}$

${ }^{178} I d$.

${ }^{179} I d$.

${ }^{180}$ Schmidt, supra note 110; Pathak et al., supra note 166, at 3.

${ }^{181}$ Pathak et al., supra note 166 , at 3 .

${ }^{182}$ Michael Hiltzik, Arizona's rules for rationing healthcare in the COVID-19 pandemic should terrify you, L.A. Times (June 30, 2020, 11:22 AM), https:/www.latimes.com/business/story/2020-06-30/hiltzikarizona-rationing-healthcare-coronavirus-covid-19.

${ }^{183}$ U.S. DeP’t Health \& Hum. Servs., State Level Crisis Standards of Care, COVID-19 Crisis Standards of Care Resource List, TRACIE (April 9, 2020), https://files.asprtracie.hhs.gov/documents/4-9-20state-level-csc-plans-guidance-policy.pdf [https://web.archive.org/web/20200410010636/https://files.asprtracie. hhs.gov/documents/4-9-20-state-level-csc-plans-guidance-policy.pdf].

${ }^{184} \mathrm{Id}$.
${ }^{185} \mathrm{Id}$.
${ }^{186} \mathrm{Id}$.
${ }^{187} \mathrm{Fl}$

${ }^{187}$ Florida Hospital Association Supports Ethics Guidelines for Crisis Standards of Care in Public Health Emergencies from Florida Bioethics Network, Fla. HosP. Ass'N (Apr. 13, 2020), http://www.fha.org/ news/show-details/Florida-Hospital-Association-Supports-Ethics-Guidelines-for-Crisis-Standards-of-Care-inPublic-Health-Emergencies-from-Florida-Bioethics-Network/56 [https://perma.cc/PQ7N-L5A7]. 
The remaining states had created plans between 2008 and 2019 which had not been updated including: Arizona, Connecticut, Washington D.C., Florida, Illinois, Maine, Michigan, Mississippi, New Jersey, New York, Ohio, Oregon, and Vermont. ${ }^{188}$ Texas was not mentioned in the HHS publication.

The six states examined in this Article are Arizona, Florida, California, Georgia, New York, and Texas. These states became "hot spots," or hubs of infected patients, during the COVID-19 pandemic and were selected for that reason. ${ }^{189}$ Arizona was also selected because it had implemented its CSC guidelines and had started the rationing process. ${ }^{190}$ It is also worth noting that in those states that have no CSC guidelines at all, the decision regarding allocation of limited resources to presenting COVID-19 patients remains based on individual, arbitrary health care provider guidelines and are not afforded the limited liability protections discussed above. ${ }^{191}$ While several state governors have issued various executive orders in an attempt to authorize their respective health departments to respond to the crisis, the executive orders do not identify particular CSC guidelines. ${ }^{192}$ Whether executive orders can confer immunity to health care providers, as opposed to legal immunity conferred by legislative action, is an issue beyond the scope of this Article. ${ }^{193}$

\section{Arizona}

Arizona's plan utilizes SOFA scoring as part of a four-step triage protocol. ${ }^{194}$ As noted above, this type of plan begins with a metric that contains exclusion categories that have a discriminatory impact on Black individuals and ethnic minorities:

STEP 1: Assign points for the triage priority score according to the individual patient's SOFA score (range from 1-4 points) ... . STEP 2: Assign additional points based on the individual evaluation of the patient and consideration of 1 year or 5 year mortality. A maximum of 4 points will be added from this step. STEP 3: Add points from STEP 1 and STEP 2 together to produce a total triage priority score, which ranges from 1-8. STEP 4: Triage color groupings are then assigned based on the triage priority score. Lower scores indicate higher likelihood of benefiting from critical care, and priority is given to those with lower scores. ${ }^{195}$

Patients receiving care may also be prioritized by group affiliation as follows ${ }^{196}$ :

According to the CSC, if two or more patients require a single resource, additional factors may be considered as priorities, including:

\footnotetext{
${ }^{188}$ U.S. DeP'T Health \& Hum. SeRvs., supra note 183.

${ }^{189}$ Stephanie Soucheray, US hot spots see COVID-19 level off, but case counts stay high, CIDRAP (Jul. 28, 2020), https://www.cidrap.umn.edu/news-perspective/2020/07/us-hot-spots-see-covid-19-level-casecounts-stay-high [https://perma.cc/CDB7-KEAB].

${ }^{190}$ Soo Kim, Arizona Activates Emergency Plan to Ration Dwindling Healthcare Resources, NewsweEK (July 1, 2020, 8:13 AM), https://www.newsweek.com/arizona-activates-emergency-plan-rationdwindling-health-care-resources-1514653 [https://perma.cc/HM46-V5P4].

${ }^{191}$ Cleveland Manchanda, et al., supra note 9.

${ }^{192}$ See supra notes 148-51.

${ }^{193}$ See, Ass'N Of State \& Territorial Health Offs., supra note 57.

${ }^{194}$ Ariz. DeP't of Health Services, Arizona Crisis Standards of Care Plan add. 4-5 (3rd ed. 2020), http://azpha.wildapricot.org/resources/covid-19-addendum.pdf [https://perma.cc/RG6D-EUWY].

${ }^{195} I d$. at 4 .

${ }^{196}$ Id. at $7-8$.
} 
1. Pediatric patients $<18$ years of age

2. First responders or frontline healthcare workers (HCWs) ...

3. Single caretakers for minors or dependent adults

4. Pregnant patients

5. Opportunity to experience life stages (childhood, young adulthood, middle years, and older years). ${ }^{197}$

"If patients requiring the same scarce resource cannot be effectively prioritized with any of the above," the CSC provides "allocation should proceed randomly." 198

The plan does include an appeals process. But there is no guarantee that the appeals process will be conducted at all: "If the family or decision maker elects to appeal the decision, another appointed Triage Officer(s) not involved in the original triage decision, if available, will be asked to review the case," and an appeal "could be denied if there is a time-critical situation and insufficient time to conduct the appeal."199

\section{2. $\quad$ Florida}

In March 2018, the Florida Department of Public Health issued a Preparedness and Response Multi-Year Training and Exercise Plan ("MYTEP"). ${ }^{200}$ This plan does not include any discussion of CSC triage protocol. ${ }^{201}$ In fact, Florida does not have a state sponsored plan for health care rationing in the event demand exceeds supply. ${ }^{202}$ Recognizing the problem, the gap was filled by the Florida Bioethics Network ("FBN"). ${ }^{203}$ The FBN plan has been endorsed by the Florida Hospital Association, which is made up of 200 hospitals. ${ }^{204}$ The FBN plan, however, is not authorized as an appropriate triage protocol by the state. ${ }^{205}$

Under the FBN plan, the decision as to how treatment will be rationed is left to each individual hospital in the state. ${ }^{206} \mathrm{FBN}$ provides that each hospital provider should form a Triage Evidence Support Team ${ }^{207}$ :

[The team will] direct decision making regarding the various and challenging criteria to be used for resource allocation and reallocation. They should have access to such expertise as the institution or its neighbors can provide. This will be a fluid and nimble process

\section{${ }^{197} I d$. at 8 .}

${ }^{198} \mathrm{Id}$.

${ }^{199}$ Id.

${ }^{200}$ Fla. Dep't of Health Bureau of Preparedness and Response, Multi-Year Training and EXERCISE PlAN (MYTEP) 2018-2020 (March 2017), https://www.ncfhcc.org/wp-content/uploads/2017/08/ 2018-2020-mytep.pdf [https://perma.cc/BRZ9-CWYV]. ${ }^{201} I d$.

${ }^{202}$ Steve Contorno \& Allison Ross, If Hospitals Get Overwhelmed, Florida is Silent on Who Survives, TAMPa BAY Times (April 19, 2020), https://www.tampabay.com/news/health/2020/04/18/if-hospitals-getoverwhelmed-florida-is-silent-on-who-survives/ [https:/perma.cc/T8L4-KYF4].

${ }^{203}$ Fla. Bioethics Network, Ethics Guidelines for Crisis Standards of Care in Public HeAlth EMERGENCIES 1 (Apr. 8, 2020), https://fha.informz.net/FHA/data/images/CSC-FBN-3.pdf [https:// perma.cc/X2F2-B3LN].

${ }^{204}$ Contorno \& Ross, supra note 202.

${ }^{205}$ FLA. Bioethics NeTwORK, supra note 203 ("No FBN members are authorized to speak on behalf of any institution they might work or volunteer for, and any listing of members' institutions is for identification purposes only. This document does not provide, and should not be inferred to provide, legal advice of any kind.").

${ }^{206}$ Id. at 6.

${ }^{207}$ Id. at 10 . 
as circumstances might worsen or abate during the period of the Guidelines' activation. Triage teams will shape, direct development of and determine activation of crisis standards policies or guidelines in consultation on any significant or nontrivial changes with the institutional leadership. ${ }^{208}$

FBN also cautions that teams need anti-discrimination training. FBN states: "Members of these teams would benefit from instruction regarding anti-discrimination laws and research describing the role of implicit and explicit bias in health care."209

The triage protocol recommends reliance on SOFA point scoring and scoring including points for comorbidities. ${ }^{210}$ In terms of prioritizing patient groups, individuals "who perform tasks vital to the public health response" will have points removed to lower their scores. ${ }^{211}$ If there is a tie, the plan impermissibly allows for the tie to be broken by considering age as a factor, which HHS has prohibited. ${ }^{212}$ FBN provides:

In the event there are ties in priority scores/categories between patients, and not enough critical care resources for all patients with the lowest scores, life-cycle considerations should be used as the first tiebreaker, with priority going to younger patients .... If there remain ties after applying life-cycle and essential-function considerations, the raw patient prioritization score should be used as a tiebreaker, with priority going to the patient with the lower score. If there are still ties after these two tiebreakers are applied, a lottery or other form of random allocation should be used to break the tie. ${ }^{213}$

\section{California}

While California has a COVID-19 emergency plan, it lacks any state triage protocol to ration care. ${ }^{214}$ The California plan provides that when staffing, supplies, and beds reach critical scarcity, "the goal of health care becomes population-based care rather than individual care." 215 This means that utilitarian ethics govern, and scarce resources are used "to do the greatest good for the greatest number rather than providing all resources needed to treat each individual." 216 The plan instructs individual physicians "to balance the obligation to save the greatest possible number of lives against the need to care for each individual." ${ }^{17}$ The plan promises that the California Department of Public Health ("CDPH") will work with experts to provide guidance on how to deliver care to ensure that "ethical principles guide decisions to withdraw or withhold care." 218

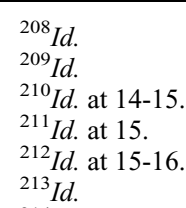

${ }^{214}$ Cal. Dep’t of Public Health, COVID-19 Healthcare System Mitigation Handbook (2020), https://mynevadacounty.com/DocumentCenter/View/33813/AFL-20-23-Mitigation-Playbook?bidId= [https://perma.cc/GM8Z-FA4C].

${ }^{215} \mathrm{Id}$.
${ }^{216} \mathrm{Id}$.
${ }^{217} \mathrm{Id}$.
${ }^{218} \mathrm{Id}$. 
CDPH issued a detailed plan for resource allocation based on the SOFA point scoring system. ${ }^{219}$ This triage protocol addresses how tied scoring should be resolved by the provider. ${ }^{220}$

In the event that there are 'ties' in SOFA or [SOFA] priority groups between patients and not enough critical care resources for all patients with the lowest scores, consideration can be given to severe medical comorbidities and advanced chronic conditions that limit near-term duration of benefit and survival. Patients who do not have a severely limited near-term prognosis for survival are given priority over those who are likely to die in the near-term, even if they survive the acute critical illness. $^{221}$

The CDPH claims that "age, disability, or any other characteristics ... do not define individuals likely to die in the near-term according to the plan;" 222 however, there is no explanation in the protocol to support this bare claim. ${ }^{223}$

At the same time, the plan recognizes the implicit racial bias in utilizing comorbidities as a determining factor for exclusion from care. ${ }^{224}$ :

Co-morbid medical conditions occur in a spectrum of severity, and should only be used in allocation decisions based on the clinical decision that they will impact near-term survival. It should be noted that due to widespread racial and ethnic health disparities, these conditions often have a higher prevalence among communities of color. Given the pervasiveness of implicit bias, it is critical that objective criteria be used to define the severity of a given comorbidity. ${ }^{225}$

What that objective criteria might be remains unclear and appears to be within the authority of each hospital provider medical triage team. ${ }^{226}$

\section{Georgia}

As of July 2020, Georgia had not developed any state triage protocols for rationing health care. ${ }^{227}$ Health care providers asked the Georgia governor to provide legal protection if the decision must be made to deny a patient a ventilator. ${ }^{228}$ There does

${ }^{219}$ Cal. Dep’t of Pub. Health, Cal. SARS-CoV-2 Pandemic Crisis care Guidelines 25 (2020), https:/www.cdph.ca.gov/Programs/CID/DCDC/CDPH\%20Document\%20Library/COVID-19/California\% 20SARS-CoV-2\%20Crisis\%20Care\%20Guidelines\%20-June\%208\%202020.pdf [https://web.archive.org/web/ 20200611173654/https:/www.cdph.ca.gov/Programs/CID/DCDC/CDPH\%20Document\%20Library/COVID-19/ California\%20SARS-CoV-2\%20Crisis\%20Care\%20Guidelines\%20-June\%208\%202020.pdf].

${ }^{220} I d$. at $27-28$.

${ }^{221} I d$.

${ }^{222} I d$.

${ }^{223} \mathrm{Id}$.

${ }^{224} I d$. ("It should be noted that due to widespread racial and ethnic health disparities, [co-morbid medical conditions] often have a higher prevalence among communities of color. Given the pervasiveness of implicit bias, it is critical that objective criteria be used to define the severity of a given comorbidity.”).

${ }^{225} \mathrm{Id}$.

${ }^{226}$ See id. at 27-28 (suggesting clinicians continue to make judgments about medical care as they would "during normal clinical practice" and providing "examples of severely life-limiting comorbidities").

${ }^{227}$ HealthCare Ethics Consortium, Current Ethics Guidance re COVID-19, https://hcecg.org/ content.aspx?page_id=22\&club_id=328955\&module_id=393105 [https://perma.cc/ZH6M-JREM].

${ }^{228}$ Ariel Hart, Georgia doctors plan for wrenching choices amid slim ventilator supply, ATLANTA J.-Const. (April 2, 2020), https://www.ajc.com/news/state--regional/georgia-doctors-plan-for-wrenchingchoices-amid-slim-ventilator-supply/wQsxpHBZ4NADgosPKG182N/ [https://perma.cc/E9HB-4WY9]. 
not appear to be any executive orders providing legal assistance as requested by providers. To fill the gap, a Georgia private organization, Emory Healthcare, Inc., has published a suggested guidelines page to provide guidance to health care providers. ${ }^{229}$ Specifically, the draft guidance is provided by Emory University and applies to rationing ventilators. ${ }^{230}$ The Emory guidelines recommend prioritization based on SOFA scoring. ${ }^{231}$ These guidelines are voluntary and without state sanction..$^{232}$

\section{New York}

New York did not release CSC to guide clinical decisions in response to the pandemic. ${ }^{233}$ In November 2015, however, New York issued Ventilator Allocation Guidelines. ${ }^{234}$ These guidelines allocate resources based on SOFA scores. ${ }^{235}$ Yet, many health care providers found these guidelines to be inadequate to address the COVID-19 pandemic. ${ }^{236}$ In fact, a state health department spokesperson advised that " [ $t$ ] $]$ he 2015 task force for life and law report is not a binding policy document and is not guiding the state's response." 237 The President of the Medical Society State of New York confirmed that emergency department physicians were essentially told: "Use your best judgement. You're on your own," when making ventilator rationing decisions. ${ }^{238}$

6. Texas

Like New York, Texas failed to release CSC guidelines in response to the pandemic. ${ }^{239}$ The Texas Department of State Health Services ("DSHS") released a plan called the Tactical Guide: Companion Document to the Texas Public Health and Medical Emergency Management 5-Year Strategic Plan, 2012-2016; ${ }^{240}$ however, this plan did not $62,63(2020)$

${ }^{229}$ Emory Healthcare, Ethics Guidance in Critical Care of Patients during the COVID-19 Public Health EmERGENCY 1 n.1 (2020), https://hcecg.org/content.aspx?page_id=22\&club_id= 328955\&module_id=393105 [https://perma.cc/5BLT-A2B4].

${ }^{230} \mathrm{Id}$. at $1 \mathrm{n} .1$.

${ }^{231} I d$. at 5 .

${ }^{232}$ Id. at 1 n. 1 .

${ }^{233}$ Tia Powell \& Elizabeth Chuang, COVID in NYC: What We Could Do Better, 20 Am. J. Bioethics

${ }^{234}$ Howard A. Zucker et al., New York State Dep't of Health, Ventilator Allocation GuIDELINES (2015), https://www.health.ny.gov/regulations/task_force/reports_publications/docs/ventilator_ guidelines.pdf [https://perma.cc/Q5PL-46E6].

${ }^{235}$ Id. at 14 .

${ }^{236}$ See Alice Park \& Jeffrey Kluger, The Coronavirus Pandemic Is Forcing U.S. Doctors to Ration Care for All Patients, TIME, April 20, 2020, https://time.com/5825145/coronavirus-rationing-health-care/ [https://perma.cc/V34H-8WW6].

${ }^{237}$ Danielle Muoio \& Amanda Eisenberg, New York hospitals rationing ventilators, retrofitting equipment amid crush of coronavirus, POLITICO N.Y. (Apr. 2, 2020), https://www.politico.com/states/newyork/albany/story/2020/04/02/new-york-hospitals-rationing-ventilators-retrofitting-equipment-amid-crush-ofcoronavirus-1270790 [https://perma.cc/X2ER-ZSV8].

${ }^{238} I d$.

${ }^{239}$ Texas has not released CSC guidelines in response to COVID-19. The Texas Department of State Health Services released guidelines but the guidelines are no longer accessible. $C f$. TeX. DeP'T of State Health Servs., Planning Resources for Public Health Preparedness Capabilities (2012), https:// dshs.texas.gov/commprep/planning/guidance/Planning-Resources-for-PHP-Capabilities_030112_FNL(2).doc [https://perma.cc/S8FA-ZPD8]; TeX. Med. Ass'N, 260.105 Statewide Crisis Standards-of-Care, https:// www.texmed.org/Template.aspx?id=45027 [https://perma.cc/6DD8-5ZER] (last updated Aug. 14, 2018).

${ }^{240}$ Tex. DeP't of State Health Servs., Tactical Guide: Companion Document to the Texas Public Health and Medical Emergency Management 5-Year Strategic Plan 2012 - 2016 (2012), https://www.dshs.state.tx.us/commprep/planning/documents/TxPHRStrategicPlanGuidel.doc [https://perma. cc/KYN6-XLFZ]. 
address triage protocols in response to a pandemic. In 2012 DSHS issued another plan as part of a national HHS initiative. ${ }^{241}$ Thereafter, in 2018, the Texas Medical Association issued a resolution to work with DSHS to create statewide CSC standards. ${ }^{242}$ What actually emerged was something very different than the anticipated statewide framework. Instead, the Texas Department of Health and Human Services left it to each individual hospital provider to "maintain a preparedness plan." 243 Like Florida, the decision as to how treatment will be rationed is left to each individual hospital in the state. ${ }^{244}$ In response, a nurses's association recommended the use of the North Texas Mass Critical Care Guidelines crafted in 2014. ${ }^{245}$ Exclusion criteria under this plan is likewise based on a modified SOFA core metric. ${ }^{246}$

As of July 2, 2020, DSHS stopped publicly reporting ICU bed availability in hospitals as COVID-19 cases reached a daily high count. ${ }^{247}$ One hospital administrator at Starr County Memorial Hospital stated publicly, "[o]ur doctors are going to have to decide who receives treatment, and who is sent home to die by their loved ones."248

\section{CONCLUSION}

As noted above, HHS has declared that individuals or entities receiving federal financial assistance may not, based on race, color, or national origin:

[D]eny services or other benefits provided as a part of health or human service programs; provide a different service or other benefit, or provide services or benefits in a different manner from those provided to others under the program; segregate or separately treat individuals in any matter related to the receipt of any service or other benefit; utilize criteria or methods of administration which subject individuals to

${ }^{241}$ See Tex. DeP't of State Health Servs., supra note 240, at 3. A medical ethics framework to support decision-making in the allocation and distribution of scarce medical resources during pandemic influenza. Tracie Healthcare Emergency Preparedness Info. Gateway, ASPR TRACIE Technical AsSISTANCE REQUEST 1 (2016), https://files.asprtracie.hhs.gov/documents/aspr-tracie-ta-crisis-standards-ofcare-state-strategies-508.pdf [https://perma.cc/8LCQ-AH29].

242“"260.105 Statewide Crisis Standards-of-Care: The Texas Medical Association will: (1) work closely with the Texas Department of State Health Services commissioner to ensure the reinvigoration of a task force charged with creating a statewide crisis standards-of-care framework; (2) support legislative efforts that promote physician-led decision-making during public health emergencies, using nationally recognized guidelines; and (3) help identify any legal barriers that would prohibit the implementation of a crisis standards-of-care framework during a declared public health emergency (Res. 301-A-17).” Tex. MeD. Ass'N, supra note 239.

${ }^{243}$ UPDATED: Key Considerations for COVID-19 Emergency Triage Policies in Texas, Ropes \& GRAY (June 26, 2020), https://www.ropesgray.com/en/newsroom/alerts/2020/04/Key-Considerations-forCOVID-19-Emergency-Triage-Policies-in-Texas [https://web.archive.org/web/20201125003146/https:/www. ropesgray.com/en/newsroom/alerts/2020/04/Key-Considerations-for-COVID-19-Emergency-Triage-Policiesin-Texas].

${ }^{244}$ See id. There is no Texas or Florida plan issued under the auspices of state government. See generally Fla. Bioethics NetWORK, supra note 205.

${ }^{245}$ N. Tex. Mass Critical Care Task Force, N. Tex. Mass Critical Care Guidelines Document (Jan. 2014), https://www.dallas-cms.org/tmaimis/dcms/assets/files/communityhealth/MCC/ GuidelinesAdult_JAN2014.pdf [https://perma.cc/T9AK-XC6Y].

${ }^{246} I d$. at 5 .

${ }^{247}$ Sarah Champagne, Texas won't specify where hospital beds are available as coronavirus cases hit record highs, TEX. TRIB. (July 2, 2020), www.texastribune.org/2020/07/02/texas-hospital-capacity-coronavirus/ [https://perma.cc/22Y6-47HE].

${ }^{248}$ Lois Parshley, Who gets to live? How doctors make impossible decisions as COVID-19 surges, NAT'L GeOGRAPHIC (July 24, 2020), https://www.nationalgeographic.com/science/2020/07/how-doctors-makeimpossible-decisions-as-coronavirus-surges-cvd/ [https://perma.cc/A235-JBBA]. 
discrimination; select a facility's site or location that excludes individuals or denies them benefits; and/or deny an individual an opportunity to participate on a planning or advisory board. ${ }^{249}$

Yet major states impacted by the spread of COVID-19, like Florida, California, Georgia, New York, and Texas, either have no statewide sanctioned triage protocol or base the decision on some version of SOFA scoring, which may penalize Black individuals and ethnic minorities previously excluded from equal access to care. ${ }^{250}$

Although the SOFA scoring system is intended to be facially neutral and objective, subjective judgments will inevitably play a role in decision making. ${ }^{251}$ To mitigate the risk of implicit bias, states have empowered triage officers and appeals committee members to review decisions, but there is no guarantee that these administrators have any expertise in equity and anti-discrimination training or come from diverse backgrounds. ${ }^{252}$

The question of enforceability of individual rights during a pandemic implicates great concern. Simply, state triage protocols that have a discriminatory disparate impact on health care rationing could result in the grave misapplication of life saving resources based on race. While still a case of first impression, courts should conclude, along with HHS, that a private right of action exists under section 1557 and that Black individuals and ethnic minorities have a right to enforce patient civil rights violations based on the theory of disparate impact discrimination arising under the implementation of facially neutral state triage protocols.

${ }^{249}$ Discrimination on the Basis of Race, Color or National Origin, supra note 87.

${ }^{250}$ Supra Section IV.C. at 3 .

${ }^{251}$ See Maves et al., supra note 48, at 213, 220; Schmidt, supra note 110; Pathak et al., supra note 166, 